WCH-410

Rev. 0
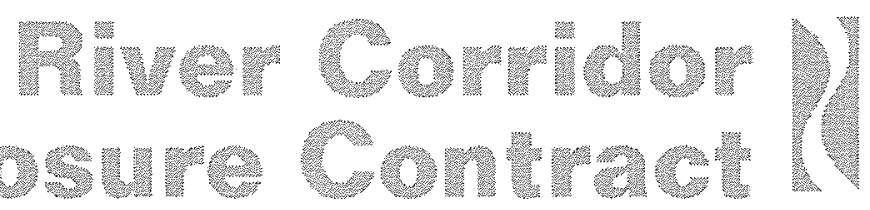

\title{
100 Area D4 Project Building Completion Report-December 2008 to December 2009
}

\section{October 2010}

For Public Release

Washington Closure Hanford

Prepared for the U.S. Department of Energy, Richland Operations Office Office of Assistant Manager for River Corridor

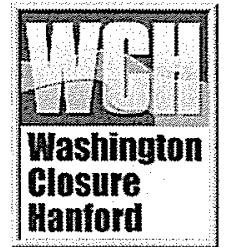


TRADEMARK DISCLAIMER

Reference herein to any specific commercial product, process, or service by trade name, trademark, manufacturer, or otherwise, does not necessarily constitute or imply its endorsement. recommendation, or favoring by the United States Government or any agency thereof or its contractors or subcontractors.

This report has been reproduced from the best available copy.

Printed in the United States of America 


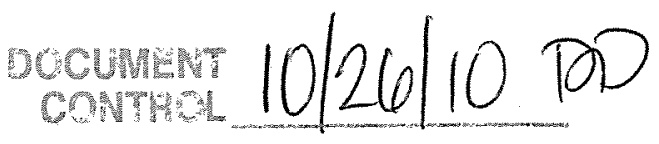

WCH-410

Rev. 0

\section{STANDARD APPROVAL PAGE}

Title: $\quad 100$ Area D4 Project Building Completion Report - December 2008 to December 2009

Author Name: K. G. Finucane, 100 Area D4 Project Analytical Lead

J.P. Harrie, 100 Area D4 Project Analytical Lead

Approval: $\quad$ M. E. Allen, 100 Area D4 Project Engineer

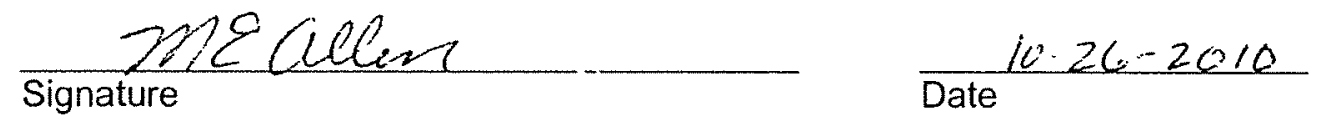

The approval signatures on this page indicate that this document has been authorized for information release to the public through appropriate channels. No other forms or signatures are required to document this information release. 
WCH-410

Rev. 0

\section{River Corridor ) Closure Contract}

\section{Area D4 Project Building Completion Report - December 2008 to December 2009}

October 2010

Authors:

K. G. Finucane

J. P. Harrie

For Public Release 


\section{EXECUTIVE SUMMARY}

This report documents the final status of buildings after the completion of deactivation, decontamination, decommissioning and demolition (D4) activities at the 100 Area of the U.S. Department of Energy (DOE) Hanford Site from December 1, 2008, to December 31, 2009. The following buildings are included in this report:

- 11-N Change Room

- $13-\mathrm{N}$ Storage Building

- 107-N Basin Recirculation Facility

- 108-N Chemical Unloading Facility

- 183-ND Resin Disposal Pit

- 183-F Clearwells

- 188-D Ash Disposal Pit

- 1524-N Hazardous Waste Storage Pad

- 1525-N Laydown Storage Area

- 1607-N1 Sewage Tank

- 1607-N2 Sewage Tank

- 1706-NA Sewage Lift Station

- 1904-D Outfall Structure

- MO-013 Mobile Office Trailer

- MO-422 Mobile Office Trailer

- MO-999 Mobile Office Trailer

Demolition debris and soil associated with completion of these buildings were disposed at the Environmental Restoration Disposal Facility (ERDF), located at the Hanford Site. Postdemolition direct hand instrument surveys and Global Positioning Environmental Radiological Survey (GPERS) surveys were performed on excavations after loadout of debris and prior to backfill.

The 100 Area D4/Interim Safe Storage (ISS) project personnel worked a total of approximately 137,930 hours (manual and non-manual, not including subcontractors) from December 1, 2008, to December 31,2009 . During this time there were 10 Occupational Safety and Health 
Administration (OSHA) recordable injuries, two of which involved lost time. There also were 27 first aid cases during this time period.

No clothing contamination and no skin contamination incidents occurred during demolition of the 100 Area buildings. Workers received 7,350.2 person-mrem of radiological exposure from December 1, 2008, to December 31, 2009 during their support of D4 activities associated with the buildings discussed in this report. All boundary air sample results were below procedural action levels for the duration of the work performed. 


\section{TABLE OF CONTENTS}

1.0 SCOPE …

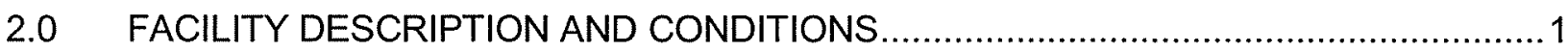

$2.1 \quad 11-N$ CHANGE ROOM CONCRETE PAD ......................................................

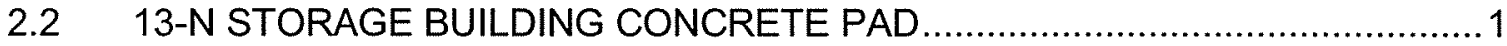

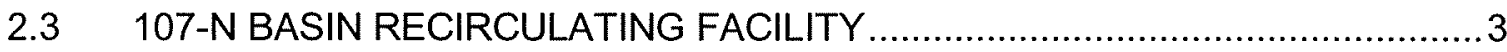

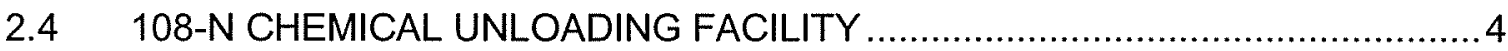

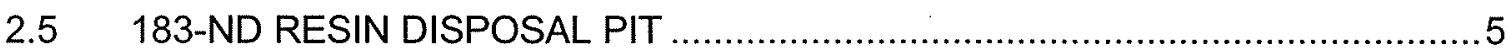

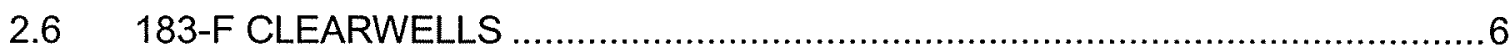

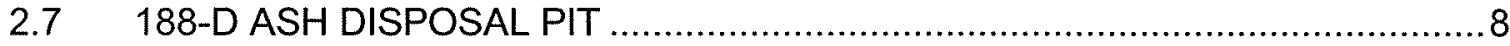

2.8 1524-N HAZARDOUS WASTE STORAGE PAD...........................................

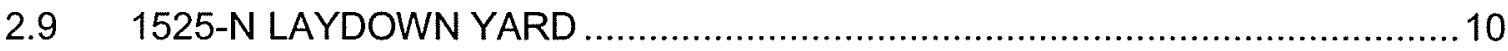

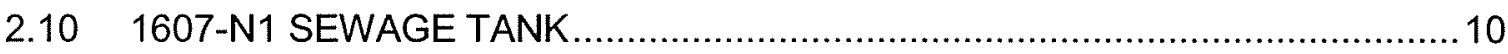

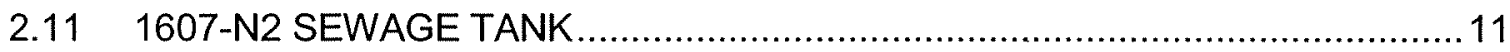

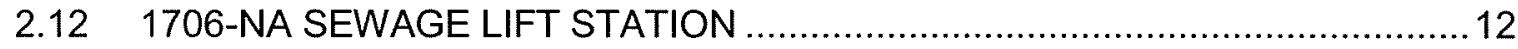

2.13 1904-D OUTFALL STRUCTURE .............................................................

2.14 MO-013 MOBILE OFFICE TRAILER ……….............................................14

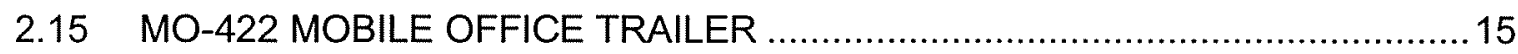

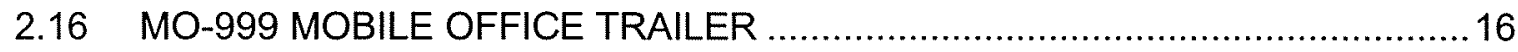

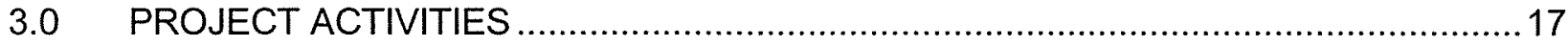

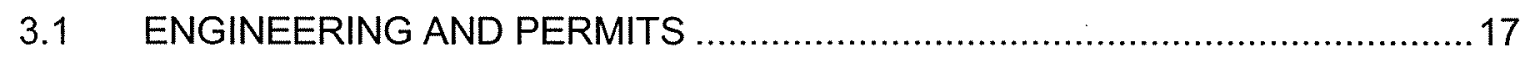

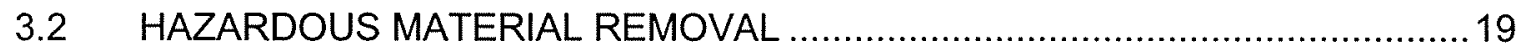

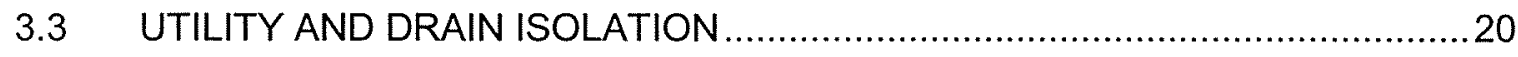

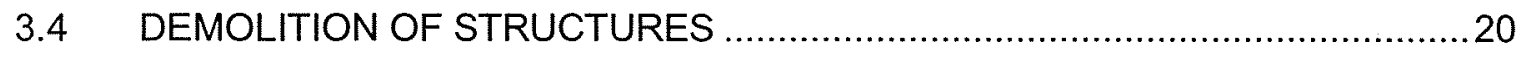

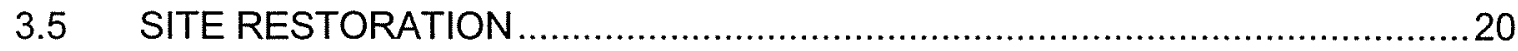

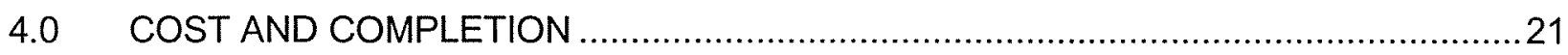

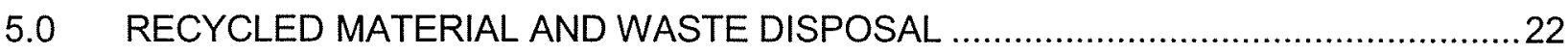




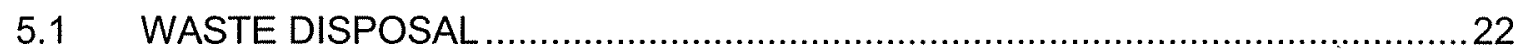

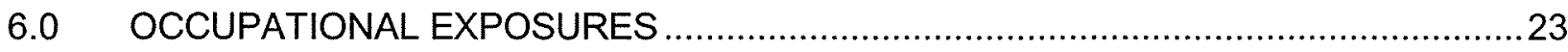

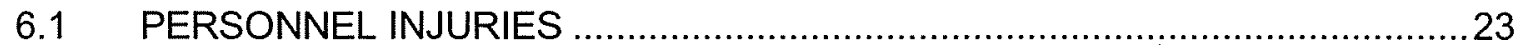

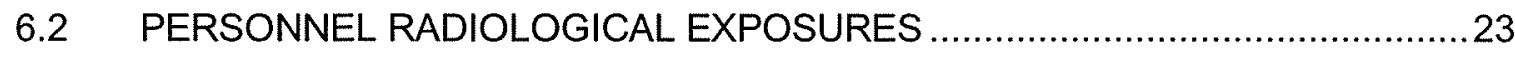

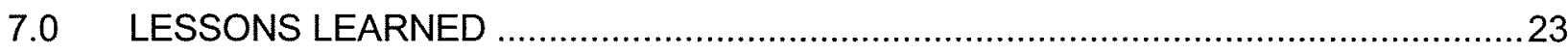

7.1 CONTROLLING EMPLOYEE ACCESS IN WORK ZONES ….........................23

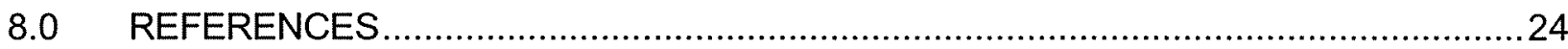

\section{FIGURES}

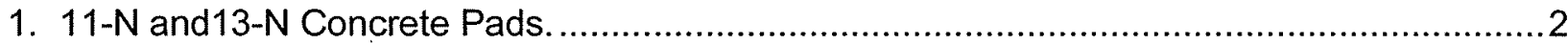

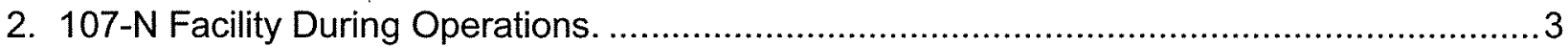

3. Post-Demolition Condition of 107-N; Inset Shows Original Structure ..................................

4. The 108-N Chemical Unloading Facility During Construction in $1961 \ldots \ldots \ldots \ldots \ldots \ldots \ldots \ldots \ldots \ldots \ldots . . .5$

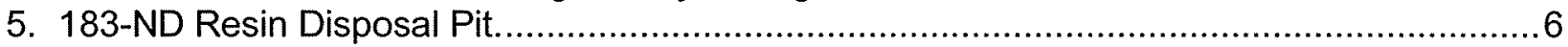

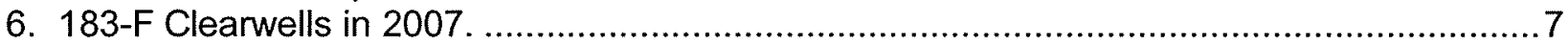

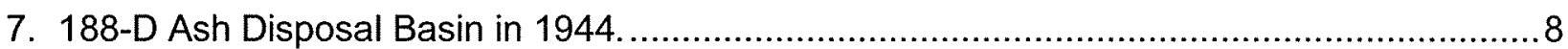

8. 1524-N Hazardous Waste Storage Pad During Operations................................................... 9

9. 1525-N Laydown Yard in 2006 .................................................................................... 10

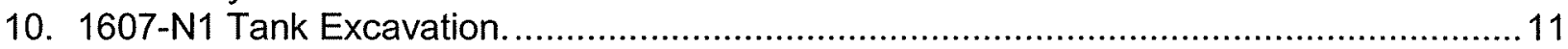

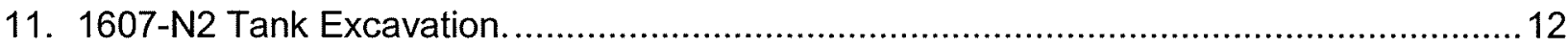

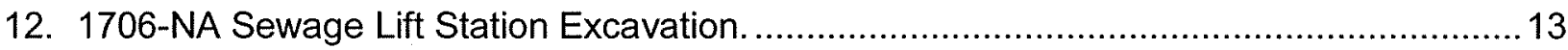

13. Demolition of the 1904-D Outfall Structure; Inset Shows Original Structure. ……..............14

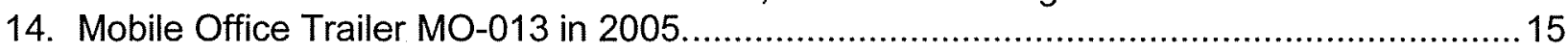

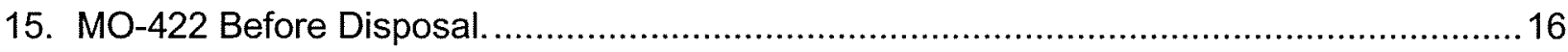

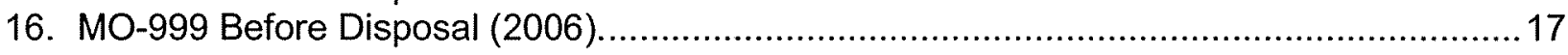

\section{TABLES}

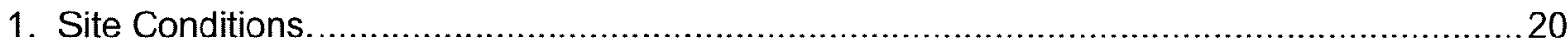

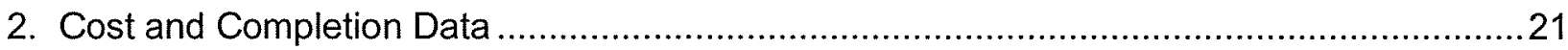

3. 100-N Demolition Project Waste Transferred to ERDF...................................................22 


\section{ACRONYMS}

D4 Deactivation, Decontamination, Decommissioning, and Demolition

DOE U.S. Department of Energy

EAL Environmental Analytical Laboratory

ERDF Environmental Restoration Disposal Facility

GPERS Global Positioning Environmental Radiological Surveyor

GPS Global Positioning System

OSHA Occupational Safety \& Health Administration

PDSR Post-Demolition-Summary-Report

RAWP Removal Action Work Plan

RCCC River Corridor Closure Contract

WCH Washington Closure Hanford, LLC

FR Field Remediation

ISS Interim Safe Storage 


\section{METRIC CONVERSION CHART}

\begin{tabular}{|c|c|c|c|c|c|}
\hline \multicolumn{3}{|c|}{ Into Metric Units } & \multicolumn{3}{|c|}{ Out of Metric Units } \\
\hline If You Know & Multiply By & To Get & If You Know & Multiply By & To Get \\
\hline Length & & & Length & & \\
\hline Inches & 25.4 & millimeters & Millimeters & 0.039 & Inches \\
\hline Inches & 2.54 & centimeters & Centimeters & 0.394 & Inches \\
\hline Feet & 0.305 & meters & Meters & 3.281 & Feet \\
\hline Yards & 0.914 & meters & Meters & 1.094 & Yards \\
\hline Miles & 1.609 & kilometers & Kilometers & 0.621 & Miles \\
\hline Area & & & Area & & \\
\hline sq. inches & 6.452 & sq. centimeters & sq. centimeters & 0.155 & sq. inches \\
\hline sq. feet & 0.093 & sq. meters & sq. meters & 10.76 & sq. feet \\
\hline sq. yards & 0.836 & sq. meters & sq. meters & 1.196 & sq. yards \\
\hline sq. miles & 2.6 & sq. kilometers & sq. kilometers & 0.4 & sq. miles \\
\hline Acres & 0.405 & hectares & Hectares & 2.47 & Acres \\
\hline Mass (weight) & & & Mass (weight) & & \\
\hline Ounces & 28.35 & grams & Grams & 0.035 & Ounces \\
\hline Pounds & 0.454 & kilograms & Kilograms & 2.205 & Pounds \\
\hline Ton & 0.907 & metric ton & metric ton & 1.102 & Ton \\
\hline Volume & & & Volume & & \\
\hline teaspoons & 5 & milliliters & Milliliters & 0.033 & $\begin{array}{l}\text { fluid } \\
\text { ounces }\end{array}$ \\
\hline tablespoons & 15 & milliliters & Liters & 2.1 & Pints \\
\hline Fluid ounces & 30 & milliliters & Liters & 1.057 & Quarts \\
\hline Cups & 0.24 & liters & Liters & 0.264 & Gallons \\
\hline Pints & 0.47 & liters & cubic meters & 35.315 & cubic feet \\
\hline Quarts & 0.95 & liters & cubic meters & 1.308 & $\begin{array}{l}\text { cubic } \\
\text { yards }\end{array}$ \\
\hline Gallons & 3.8 & liters & & & \\
\hline cubic feet & 0.028 & cubic meters & & & \\
\hline cubic yards & 0.765 & cubic meters & & & \\
\hline Temperature & & & Temperature & & \\
\hline Fahrenheit & $\begin{array}{l}\text { subtract } 32 \text {, } \\
\text { then multiply } \\
\text { by } 5 / 9\end{array}$ & Celsius & Celsius & $\begin{array}{l}\text { multiply by } 9 / 5 \text {, } \\
\text { then add } 32\end{array}$ & Fahrenheit \\
\hline Radioactivity & & & Radioactivity & & \\
\hline picocuries & 37 & millibecquerel & Millibecquerels & 0.027 & Picocuries \\
\hline
\end{tabular}




\subsection{SCOPE}

This report documents the final status of buildings demolished at the 100 Area of the

U.S. Department of Energy (DOE) Hanford Site from January 1, 2009, to December 31, 2009. The following buildings are included in this report: 11-N, 13-N, 107-N, 108-N, 183-ND, 183-F, 188-D, 1524-N, 1525-N, 1607-N1, 1607-N2, 1706-NA, 1904-D, MO-013, MO-422, and MO-999.

The activities at these facilities generally included utility disconnection, planning, characterization, engineering, removal of hazardous and radiologically-contaminated materials, equipment removal, deactivation, decontamination, decommissioning, and demolition of the above-grade structure, and removal of the remaining slabs and foundation elements, "load-out" of debris to Hanford's Environmental Restoration Disposal Facility (EDRF), followed by backfill.

All but two of the buildings discussed in this report were demolished between December 2008 and December 2009. Previous reports discuss 100 Area building D4 activities that were completed before December 2008. Buildings 183-ND and 13-N are reported here because they were not included in the previous building completion report $(\mathrm{WCH} 2009)$ covering the timeperiod in which they were demolished.

\subsection{FACILITY DESCRIPTION AND CONDITIONS}

The buildings detailed in this report were located in the 100 Area of the Hanford Site. This area was constructed and operated for the production of plutonium. All but two of the buildings discussed in this report were located at the 100-N Area; the remaining two were located at $100-\mathrm{D}$, which is adjacent to and northeast of $100-\mathrm{N}$.

\subsection{1-N CHANGE ROOM CONCRETE PAD}

The 11-N Building (formally a portable storage building and change facility) was demolished in 2004. Concrete pads located west and north of the 11-N Building were demolished in 2007. The remaining concrete pad was demolished in December of 2008 (Figure 1). Concrete debris associated with the demolition of the concrete pad was disposed of at ERDF. Soil material from 100-N Borrow Pit was used to backfill the resultant excavation and the site was downposted and released. Final D4 documentation includes the Global Positioning Environmental Radiological Surveyor (GPERS) radiological survey, the Global Positioning System (GPS) survey, and sample data, all of which are included in the Post-Demolition Summary Report (PSDR) (WCH 2009b).

\subsection{3-N STORAGE BUILDING CONCRETE PAD}

The 13-N building (formerly a $20-\mathrm{ft}$ by $40-\mathrm{ft}$ portable storage area for pipe fitters) was demolished in 2004 and the demolition debris disposed of at ERDF. A concrete pad to the east of the building measuring $80-$ by $20-\mathrm{ft}$ also was considered as part of $13-\mathrm{N}$ (BHI 1995). 
The remaining concrete pad (Figure 1) was demolished in December 2008 and debris associated with the demolition was disposed of at EDRF. Soil material from 100-N Borrow Pit was used to backfill the excavation, which was downposted and released. Final D4 documentation includes the GPERS and GPS surveys and sample data, all of which are included in the PDSR (WCH 2009b).

Figure 1. 11-N and13-N Concrete Pads.

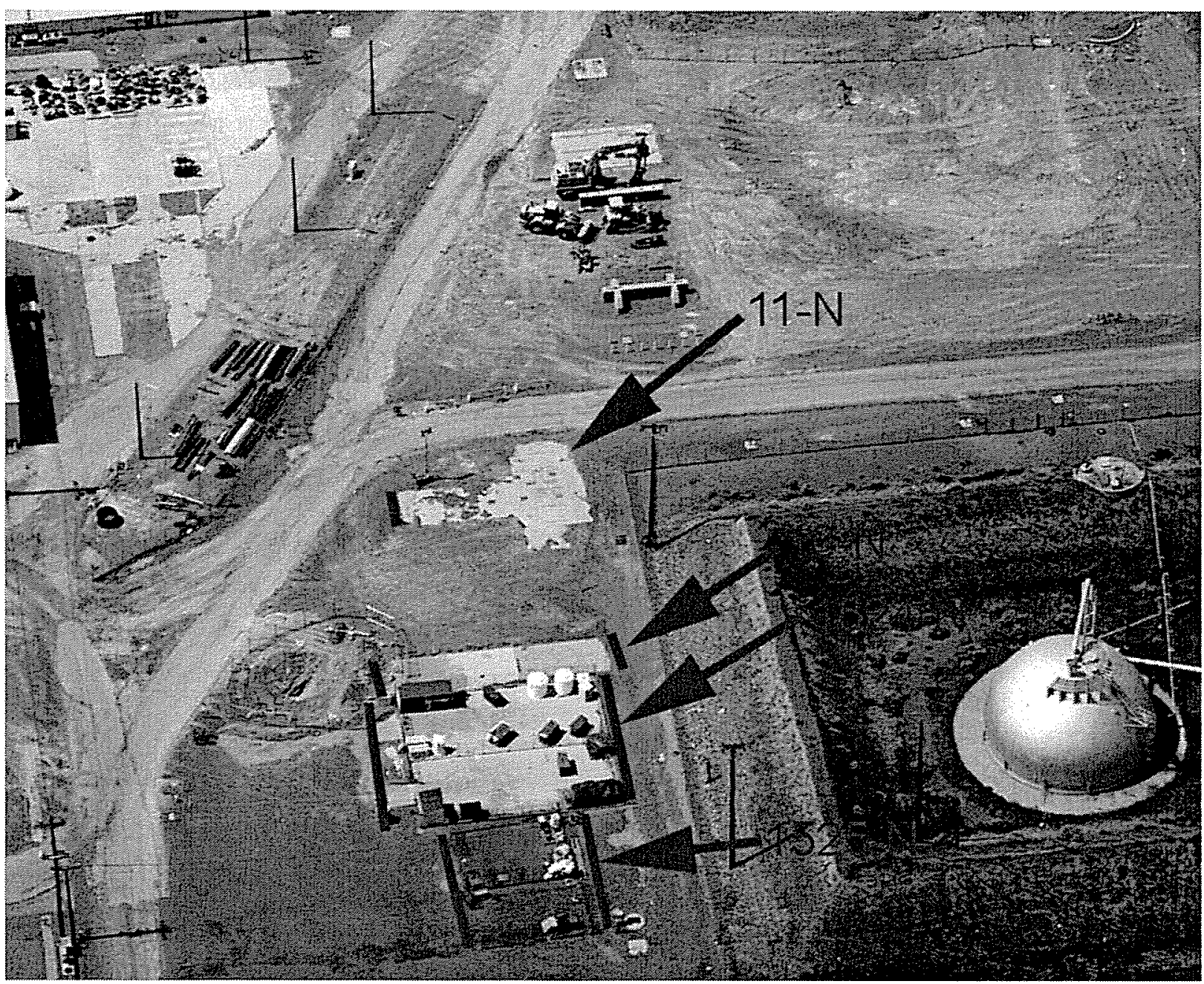




\subsection{7-N BASIN RECIRCULATING FACILITY}

The 107-N Basin Recirculation Facility was a two-story reinforced-concrete structure approximately $47-\mathrm{ft}$ wide by $69-\mathrm{ft}$ long by 48 -ft high. The $107-\mathrm{N}$ building was located $328 \mathrm{ft}$ west of the 105-N Reactor and $131 \mathrm{ft}$ ) from the Columbia River (Figure 2). 107-N was operational between 1984 and 1989 and primarily housed the equipment to cool, filter, and demineralize $105-\mathrm{N}$ fuel storage basin water. The105- $\mathrm{N}$ basin water and suspended solids were collected in overflow weirs at the surface of the $105-\mathrm{N}$ basin pool, and then piped by gravity to the $107-\mathrm{N}$ Building pump well, which was further pumped through process equipment before returning to the basin (DOE/RL 2004).

Figure 2. 107-N Facility During Operations.

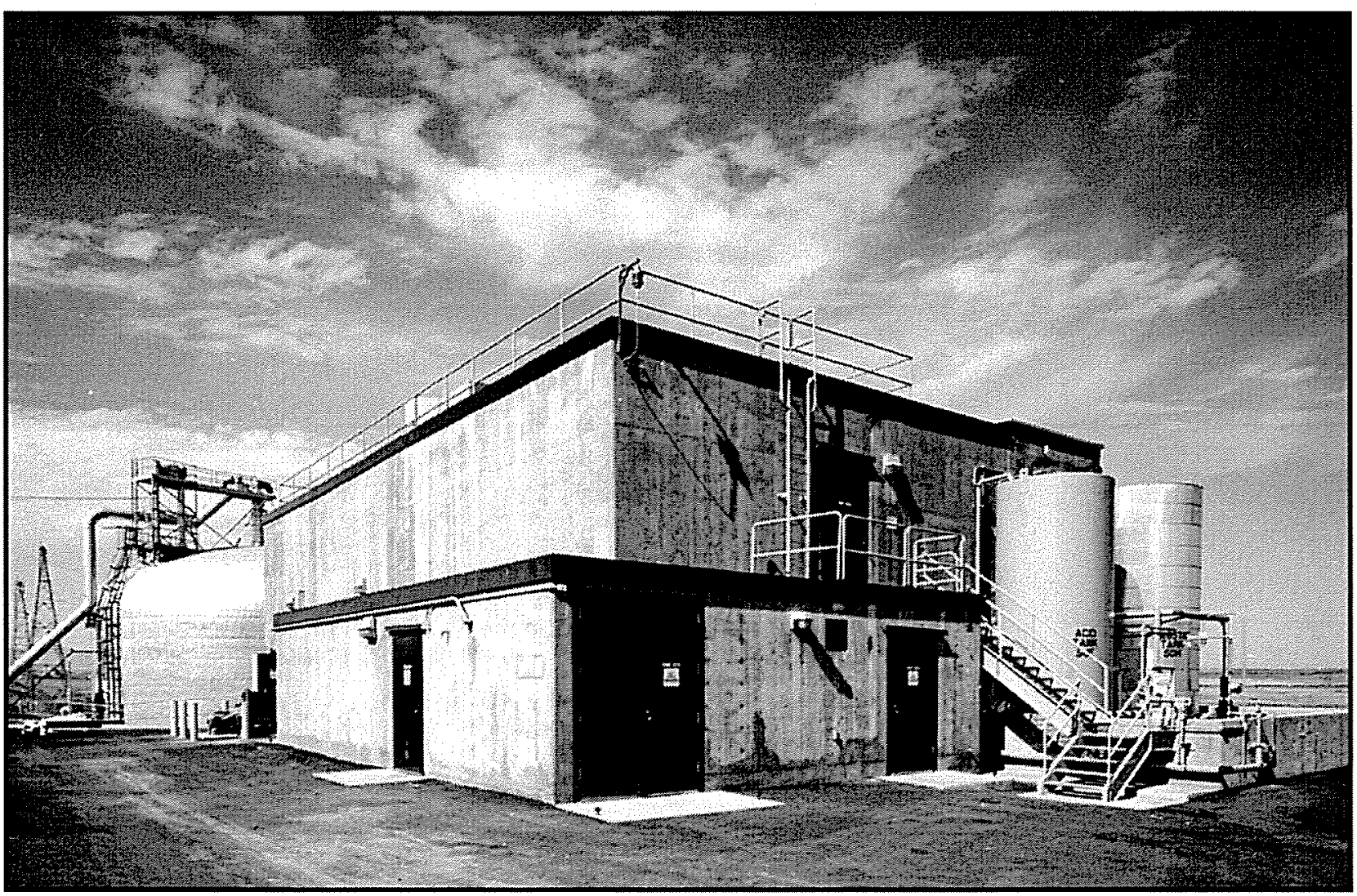

The 107-N Facility consisted of a ground floor, basement, and a partial second floor. The floors of the facility consisted of reinforced concrete or metal grating. The roof was pre-cast concrete. A control room was located on the second floor and had its own access separate from the main building entrances. A concrete-bermed annex with a metal weather enclosure that housed caustic and acid tanks was located on the north side of the 107-N building.

Facility components included: a pump well and two recirculation pumps, two heat exchangers, two sand filters, a sand filter backwash tank ( $T-1$ tank), three ion exchange vessels (2-cation, 1-anion), one caustic tank, one acid tank, one regeneration waste collection tank (T-4 tank removed under Environmental Restoration Contractor), one resin loadout tank (T-5 tank), three building sumps, and one hydrogen peroxide tank and pump. 
The majority of the 107-N Facility was demolished in 2009. The basement floor and the belowgrade portion of the east wall were left in place pending demolition of the $105-\mathrm{N}$ fuel storage basin (Figure 3). Tanks and filters were removed during demolition and disposed of at ERDF. Their contents had been previously stabilized, or removed, treated, and disposed at ERDF. Demolition debris also was disposed at ERDF. The site was partially backfilled using material from the 100-N Borrow Pit. Typical final D4 information such as the post-demolition GPERS radiological survey and the GPS survey reports have not been fully compiled because the building demolition is not complete.

Figure 3. Post-Demolition Condition of 107-N; Inset Shows Original Structure.

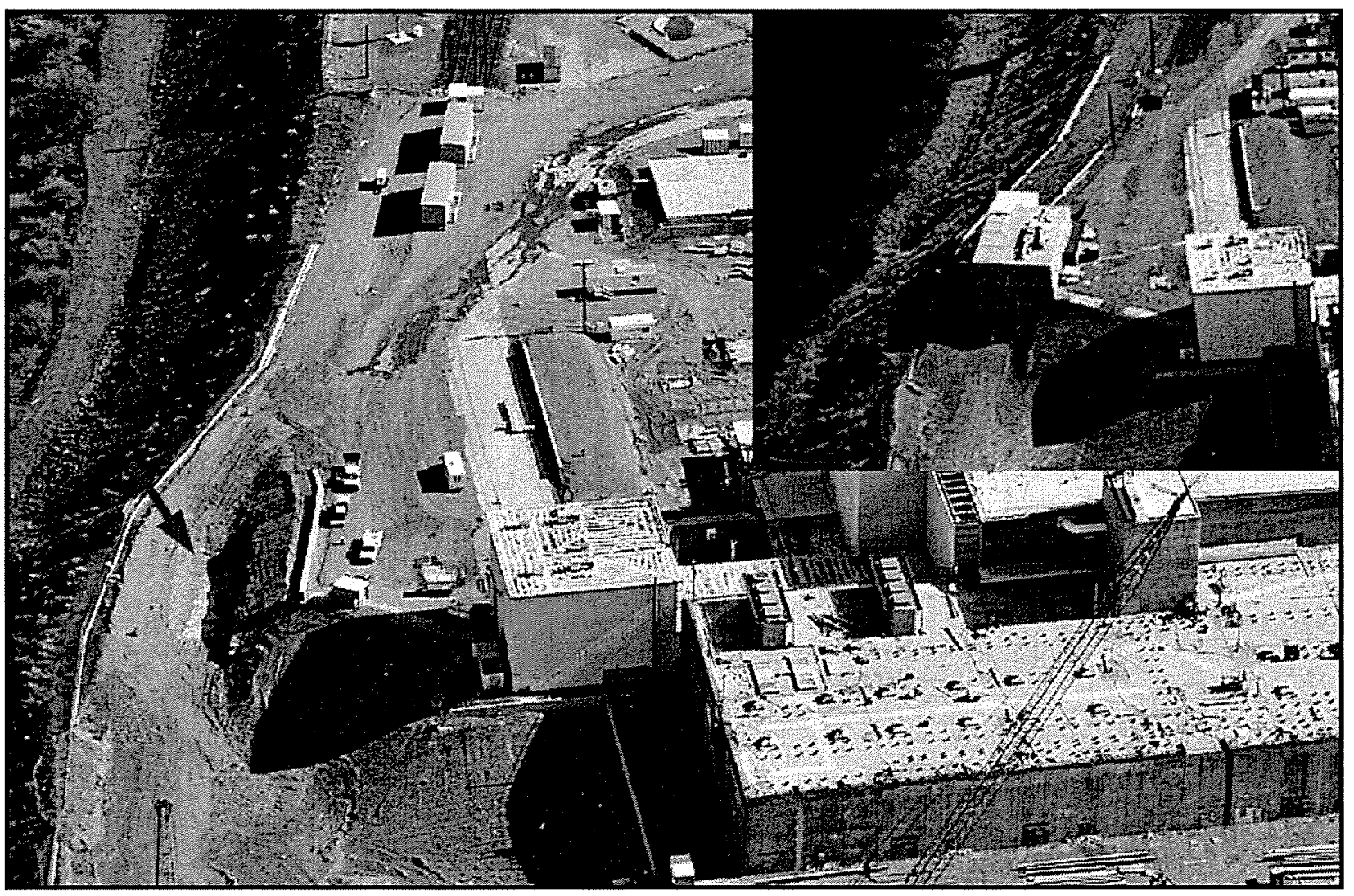

\subsection{8-N CHEMICAL UNLOADING FACILITY}

The 108-N Chemical Unloading Facility consisted of several parts, a single story $27 \mathrm{ft}$ by $30 \mathrm{ft}$ pump house, three acid storage tanks, one caustic storage tank and a pneumatic transfer tank (Figure 4). A covered underground neutralization pit was located adjacent to the pump house. A tank car unloading station was located east of the pump house and adjacent to the railroad (BHI 1995). 
The 108-N Chemical Unloading Facility and 120-N-5 Transfer Pipes and Neutralization Pit were demolished in 2006-2008. After demolition was completed the concrete debris was stockpiled, sized reduced, loaded out, and disposed of at ERDF. Soil material from 100-N Borrow Pit was used to backfill the site, which has since been downposted and released. Final D4 documentation includes the GPERS and GPS surveys and sample data, all of which are included in the PDSR (WCH 2005b).

Figure 4. The 108-N Chemical Unloading Facility During Construction in 1961.

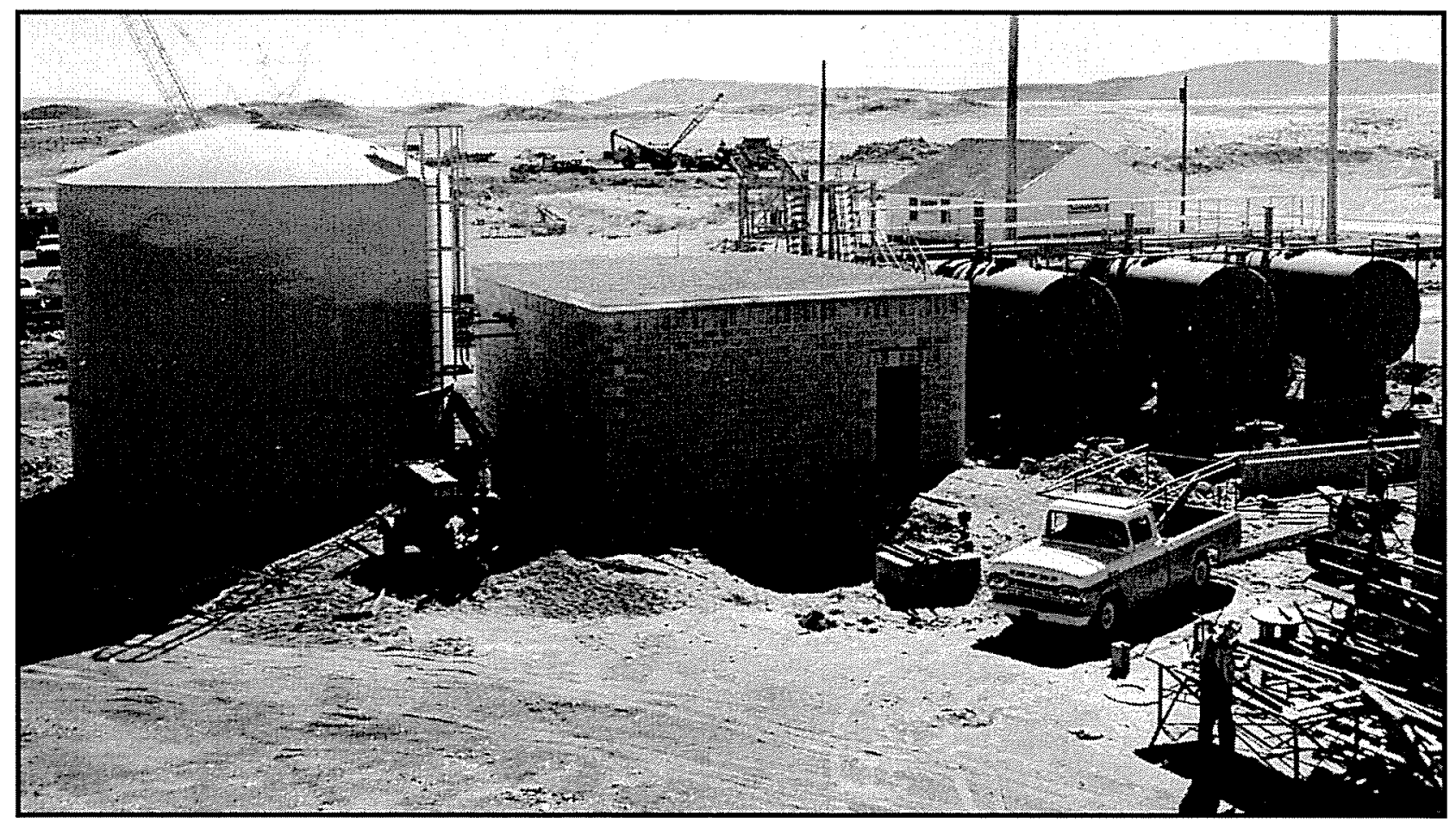

\subsection{3-ND RESIN DISPOSAL PIT}

The 183-ND Resin Disposal Pit (Waste Information Data System [WIDS] site 100-N-23) was an open rectangular pit approximately 80 -ft long by 35 -ft wide and $15-\mathrm{ft}$ deep with a 24 -in. drain pipe protruding horizontally from the north side into the pit (Figure 5). The pit was used to dispose spent resin from the 163-N Demineralization Plant. The pit later served as the 183-NB Clearwell overflow. Although the pit was not used for either of the intended purposes after 1990, it remained in place for use on an emergency basis. Between 1990 and 1992, the resin was excavated from the pit (WCH 2009e).

A pre-existing wood fence around the pit was demolished and removed along with miscellaneous wood and concrete debris. Demolition material was loaded into roll-off containers and shipped to ERDF for disposal under Waste Profile No. HGP001 (WCH 2010a). Final D4 documentation includes the GPERS and GPS surveys and sample data, all of which are included in the post-demolition summary report (WCH 2009e). 
The physical pit still exists and is surrounded by a temporary metal cyclone fence for safety. All above-grade demolition was performed per D4 removal action requirements; the completion date was June 30, 2008. Removal of the remaining inlet pipe, any below-grade work and backfill will be performed by Washington Closure Hanford (WCH) Field Remediation (FR) project.

Figure 5. 183-ND Resin Disposal Pit.

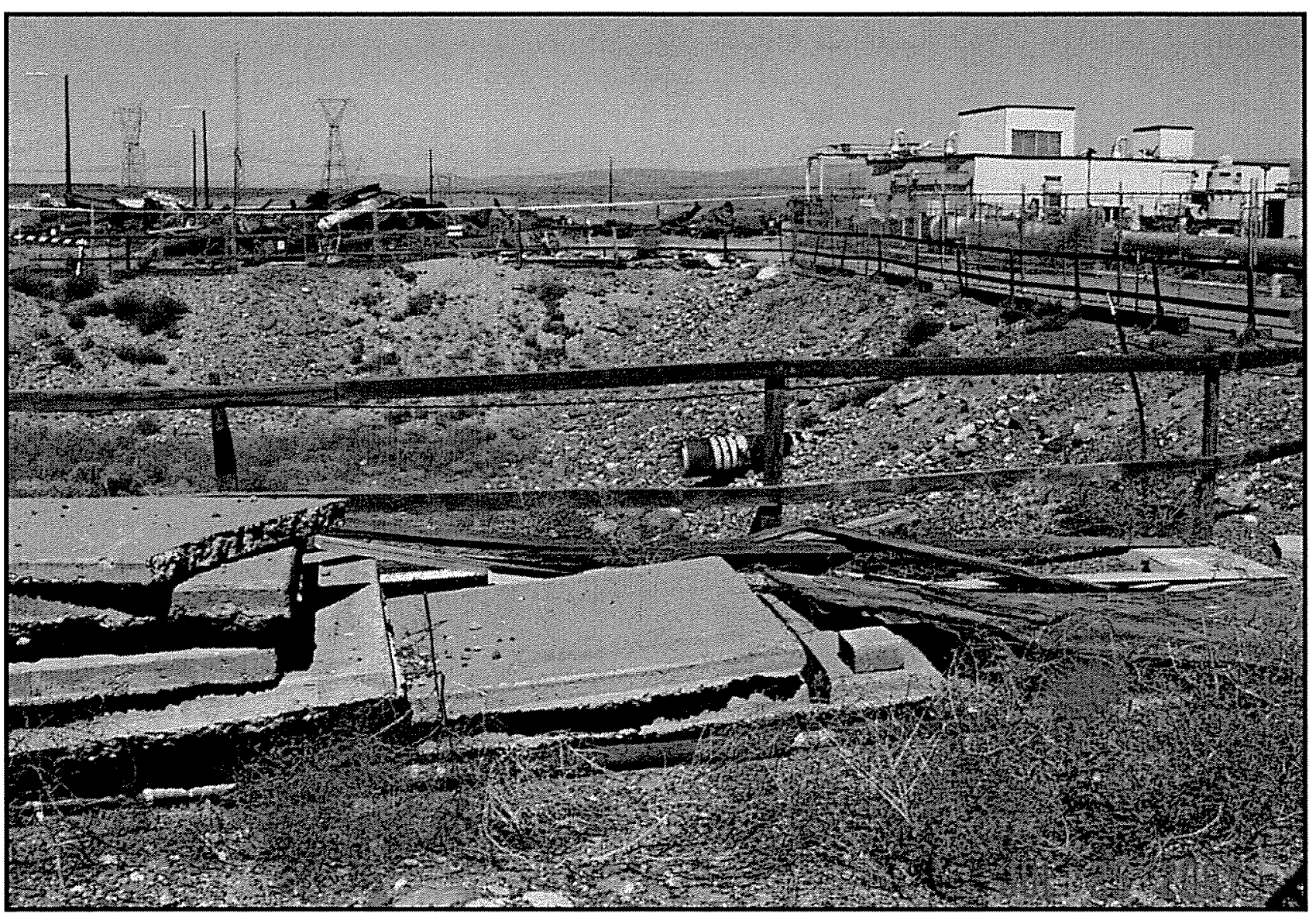

\subsection{3-F CLEARWELLS}

The 183-F Filter Plant, located to the north of the 105-F Reactor Building, was designed to treat raw river water before it entered the reactor. It consisted of the following structures: head house, flocculation and sedimentation basins, filter building, clearwells (Figure 6) and pump house. All facilities, except the clearwells, were demolished in 1977 and covered with soil.

Each of the two reinforced concrete clearwells stored 4.5 million-gal of treated water from the filter building, which was pumped as needed to the reactor cooling system. Beginning in the 1970s, the eastern clearwell received demolition wastes from the 183-F, 185-F, 189-F, 1717-F, and 190-F Buildings, as well as uncontaminated portions of the 115-F Building (BHI 1994).

Site remediation was performed from July to September 2005 and included of the removal of debris within the eastern clearwell structure down to the concrete floor. Excavated material was staged onsite before ERDF disposal. Radiological surveys and visual inspection of the 
remediated clearwell structure revealed no residual contamination on the concrete floor or sidewalls and no indication of possible contaminant migration beyond the boundaries of the clearwells. No remediation or investigation was performed at the western clearwell, as no waste materials were disposed there, and the roof of the facility remains intact. The clearwells received interim closeout status in $2006(\mathrm{WCH} 2006 \mathrm{~b})$. The site has been downposted and released.

In 2006 a maternity bat colony, estimated to be approximately 2,000 bats and the largest known colony in eastern Washington, was discovered at the 183-F west Clearwell facility (126-F-2 waste site) that was planned for demolition. Between June 2007 and September of 2008, an ecological study recognized the ecological significance of the 183-F west Clearwell and identified a preferred alternative that included leaving the clearwell and flumes in-place and installing fencing and signage to protect the bat colony.

Because the 183-F Clearwells were upstream of sodium dichromate additions to cooling water, and the 183-F east Clearwell was demolished and the Remaining Sites Verification Package (RSVP) supporting Waste Site Reclassification Form 2006-017 stated that the waste removal action achieved compliance with remedial action objectives, the site was interim closed. In March of 2009, DOE and the EPA approved the activities described in WCH-312, Identification and Protection of a Bat Colony in the 183-F Clearwell: Mitigation of Bat Habitat on the Hanford Site (WCH 2009a), leaving the west Clearwell as Bat habitat. The decision was described in the Record of Decision addressing the 100-F Area.

Figure 6. 183-F Clearwells in 2007.

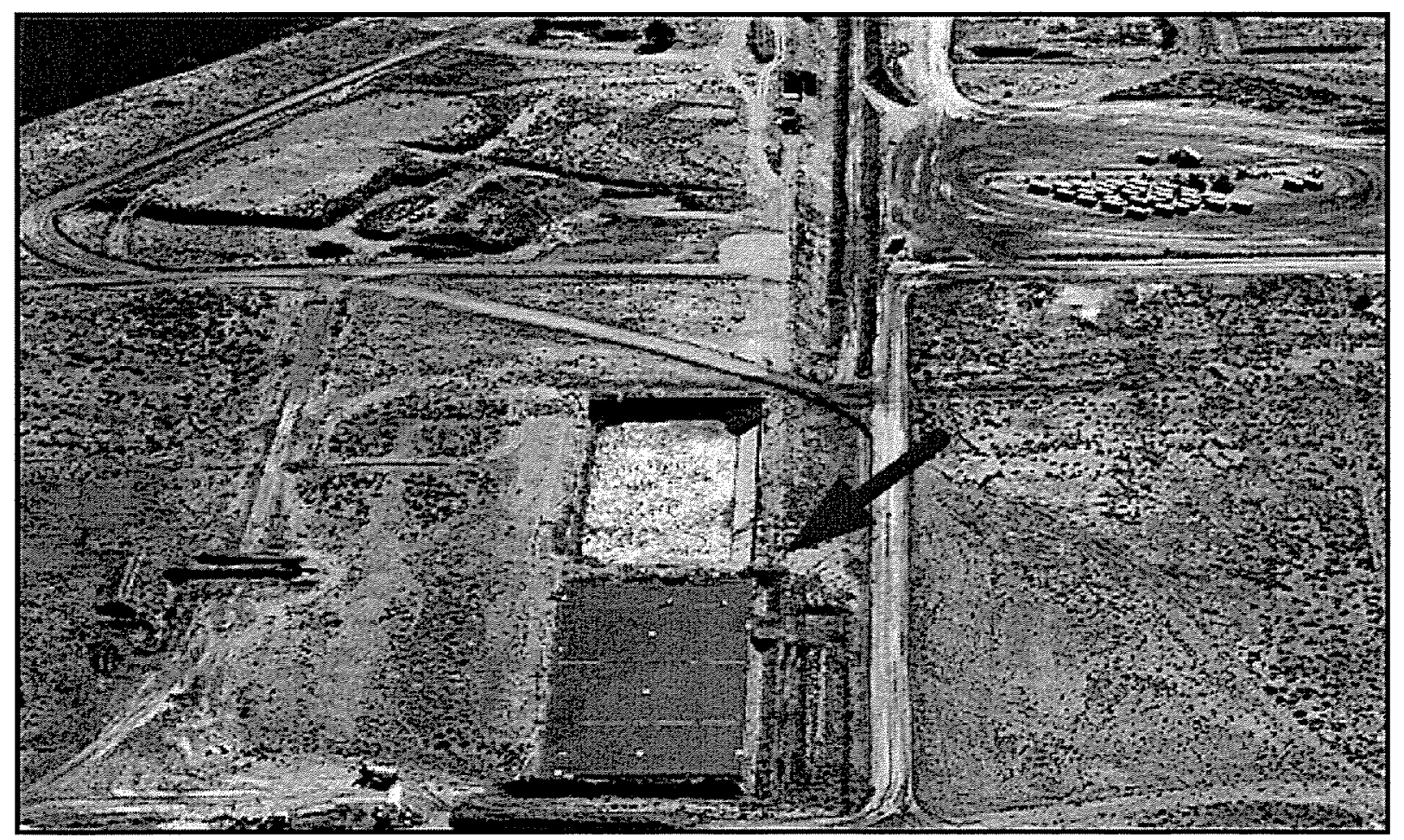




\section{$2.7 \quad$ 188-D ASH DISPOSAL PIT}

The 188-D Ash Disposal Pit was a rectangular basin that $260 \mathrm{ft}$ by $290 \mathrm{ft}$ by $13.5 \mathrm{ft}$ (Figure 7 ). It was originally constructed as a pit to hold ash from the 184-D-31 Power House. Ash was pumped directly from the power house to the pit by means of an 8-in. cast-iron underground pipeline. From 1944, until the pit was retired in 1966, it received ash/water effluent from the power house. Between 1966 and 1977, the pit received no discharges. Between 1977 and 1979, two ponds were constructed in the 188-D Ash Disposal Pit. These ponds (the 100-D Ponds; WIDS site code 120-D-1) were used as a land surface impoundment for the disposal of primarily non-radioactive, non-dangerous liquid effluents from the 183-D Water Treatment Facility.

The100- D ponds were remediated in 1996 and received closure certification in 1999. In June 1998, the 126-D-1 waste site (188-D Ash Disposal Pit) was reclassified as rejected based on information indicating that ash from Hanford Site power plants is not radioactive and not a dangerous waste (BHI 1998b). The 188-D Ash Disposal Pit was left in place. There were no down-posting or GPERS surveys associated with the 188-D Ash Disposal Pit because it was never posted for radiological contamination (WCH 2010a).

Figure 7. 188-D Ash Disposal Basin in 1944.

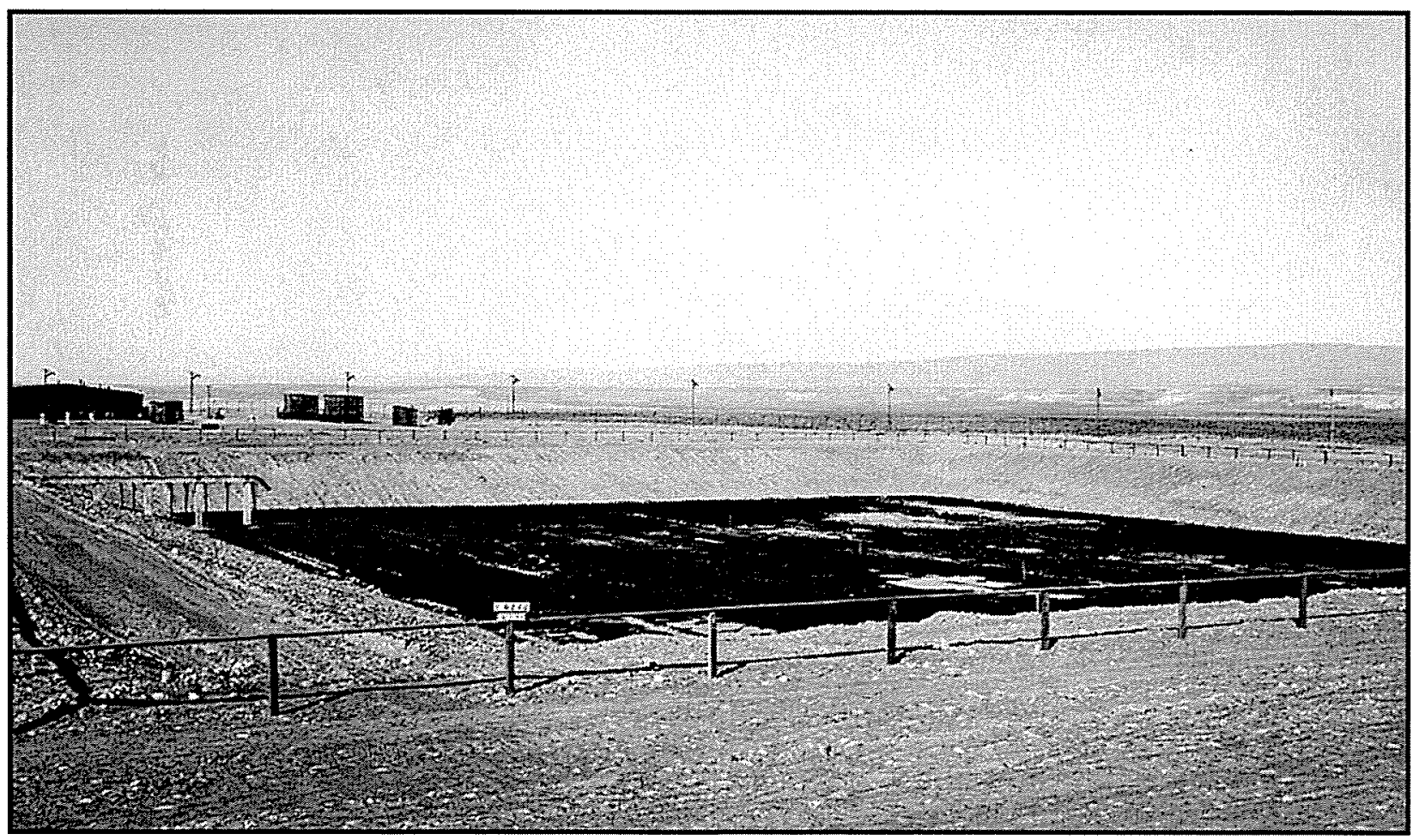




\subsection{4-N HAZARDOUS WASTE STORAGE PAD}

The 1524-N Hazardous Waste Storage Pad consisted of a curbed concrete pad approximately $80 \mathrm{ft}$ by $80 \mathrm{ft}$, enclosed with a chain link fence (Figure 8 ). Two small wood sheds ( $8 \mathrm{ft}$ by $20 \mathrm{ft}$ and $8 \mathrm{ft}$ by $10 \mathrm{ft}$ ), each with one side open, were located on the south end of the pad. 1524-N was located south of the 1310-N "Golf Ball" and between the 13-N and 1525-N facilities.

$1524-\mathrm{N}$ began operation in 1985 and was used to store drums and other containers of waste materials until 1989. During N-Area deactivation it was used for the storage of radioactive materials including shipping casks and shielded containers.

The 1524-N Storage Pad was demolished and excavated in December 2008. The demolition material was loaded into roll-off containers and sent to ERDF for disposal. Soil material from 100-N Borrow Pit was used to backfill the site, which has since been downposted and released. Final D4 documentation includes the GPERS and GPS surveys and sample data, all of which are included in the PDSR (WCH 2009b).

Figure 8. 1524-N Hazardous Waste Storage Pad During Operations.

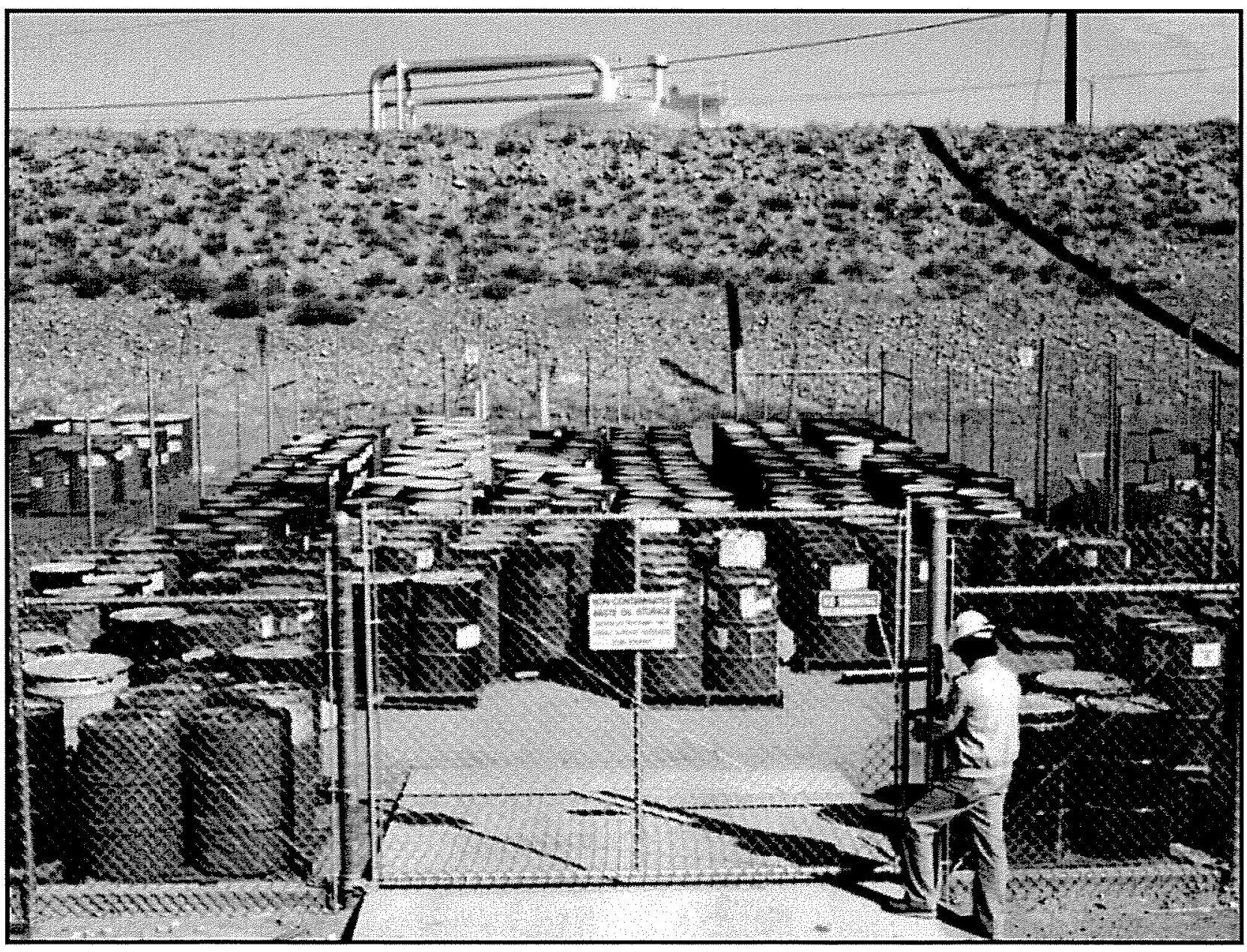




\section{$2.9 \quad 1525-N$ LAYDOWN YARD}

The 1525- $\mathrm{N}$ facility was a 40 -ft by $60-\mathrm{ft}$ graveled laydown storage yard enclosed with a chain link fence (Figure 9). It was located south of the 1310-N "Golf Ball" and was on the east side of $1524-N$. 1525-N was a fenced laydown yard to prevent unauthorized removal of materials stored in the area. The facility was used for storing construction materials, and no contamination events are known to have occurred.

The 1525-N Storage Area was demolished in December 2008. The demolition material was loaded into roll-off containers and disposed at ERDF. The excavation was backfilled with material from the 100-N Borrow Pit, and the site has been downposted and released. Final D4 documentation includes the GPERS and GPS surveys and sample data, all of which are included in the PDSR (WCH 2009b).

Figure 9. 1525-N Laydown Yard in 2006.

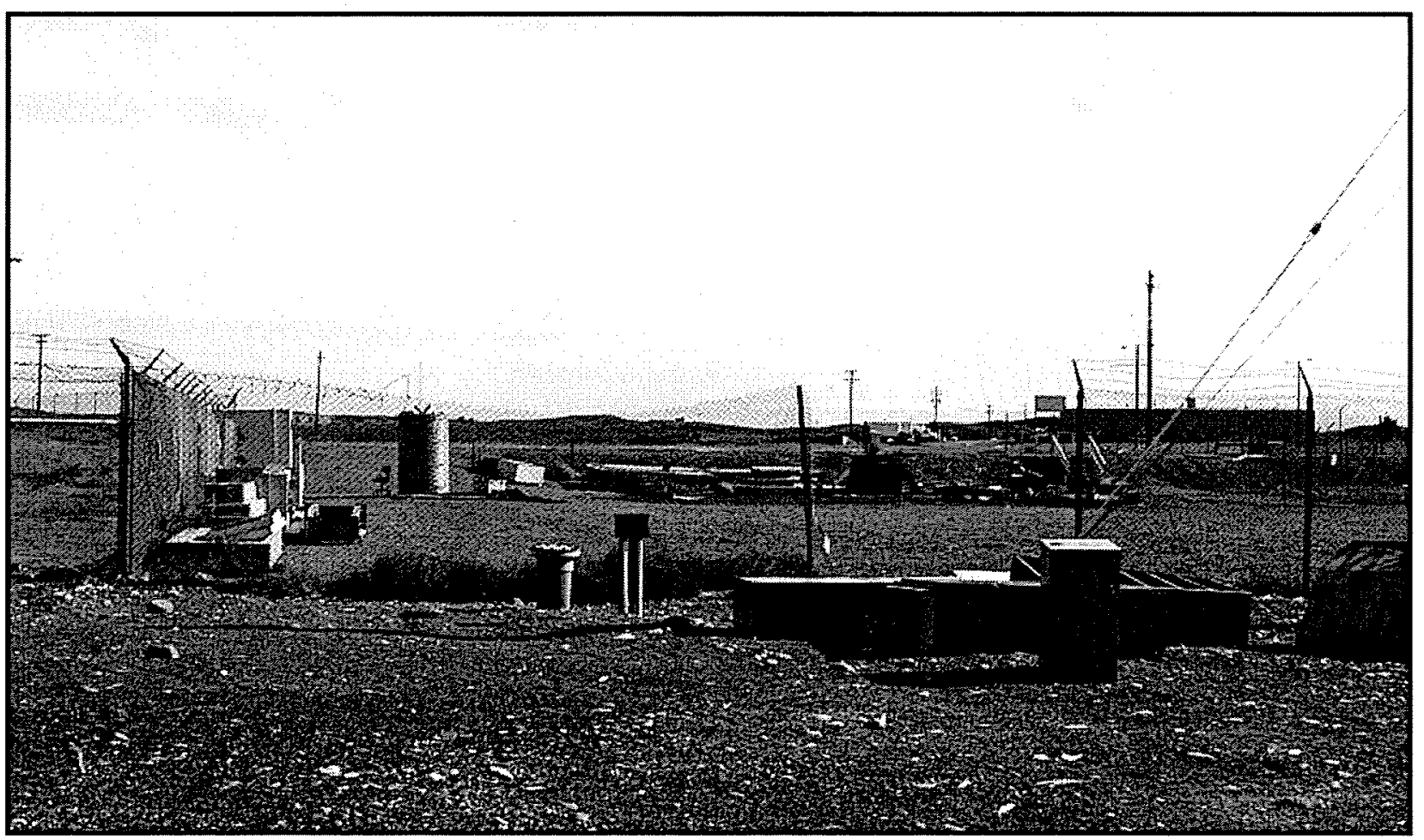

\section{$2.10 \quad 1607-N 1$ SEWAGE TANK}

The 100-N Sanitary Sewer System No. 1 Tank (1607-N1 Sewage Tank) was located $45 \mathrm{ft}$ south of 163-N Water Demineralization Plant. The unit included a septic tank and a cesspool. The tank received an estimated 1,400 gallons/day of sanitary waste from 163-N/183-N Buildings and operated from 1963 to 1996 , when it was drained and deactivated. 
The tank was demolished and excavated in September 2009 (Figure 10). Debris was disposed of at ERDF. The cesspool was not removed and is to be remediated by FR. The excavation was backfilled with material from the 100-N Borrow Pit, and the site has been downposted and released. Final D4 documentation includes the GPERS and GPS surveys and sample data, all of which are included in the PDSR (WCH 2009c).

Figure 10. 1607-N1 Tank Excavation.

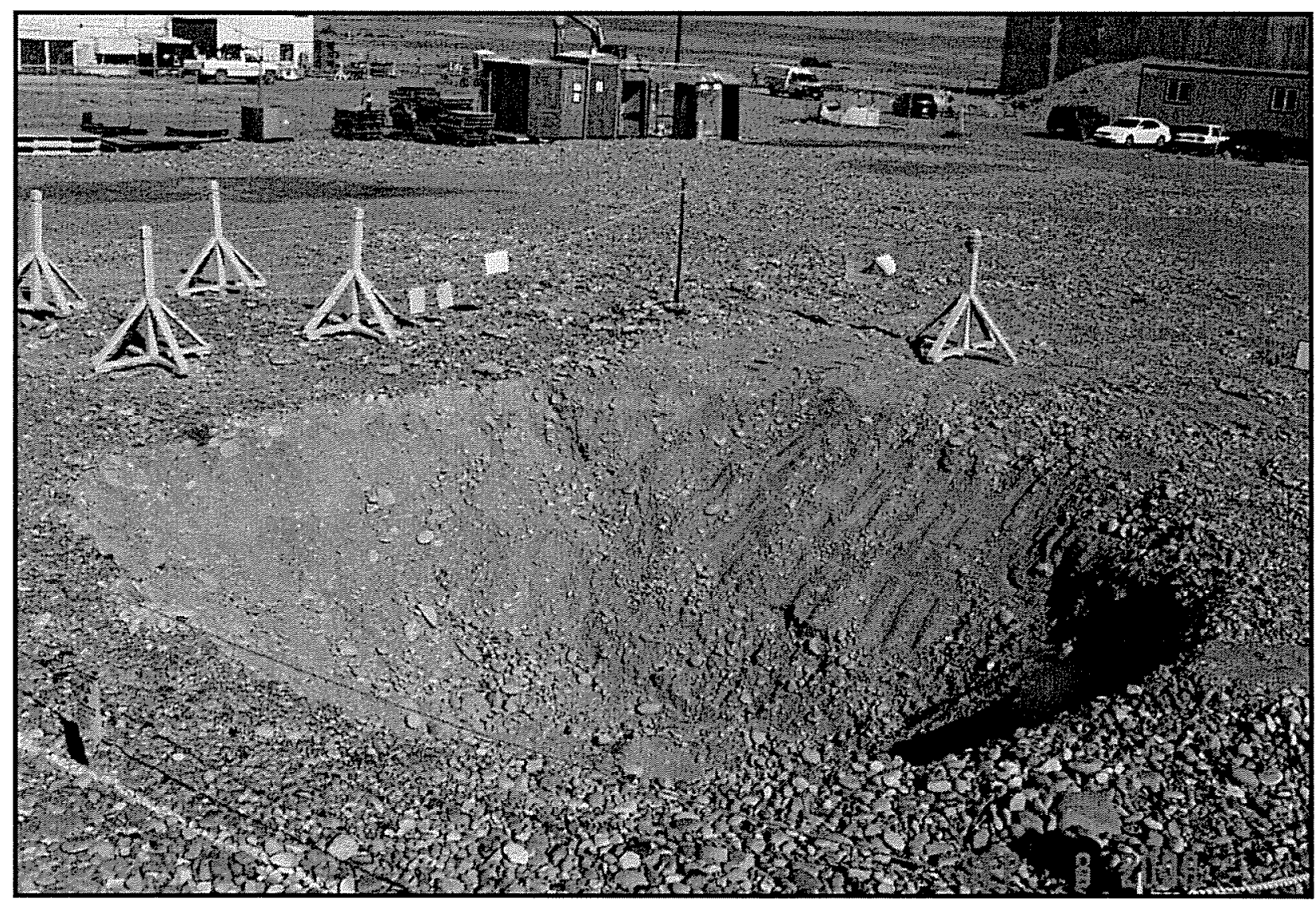

\section{$2.11 \quad 1607-N 2$ SEWAGE TANK}

The 100-N Sanitary Sewer System No. 2 Tank (1607-N2 Sewage Tank) was located southeast of 182-N High-Lift Pump House. The unit included a septic tank and cesspool. The unit received an estimated 200 gallons/day of sanitary waste from 182-N Building and operated from 1963 through 1987. The tank was pumped and isolated after the 124-N-10 Septic Treatment Facility was placed in service in February 1987.

Tank 1607-N2 was demolished and excavated (Figure 11). Following disposal of debris and soil to ERDF, the site was backfilled to facilitate safe removal of the 182-N Building. The excavation was backfilled with material from the 100-N Borrow Pit, and the site was downposted and released. Final D4 documentation includes the GPERS and GPS surveys and sample data, all of which are included in the PDSR (WCH 2009d). 
Figure 11. 1607-N2 Tank Excavation.

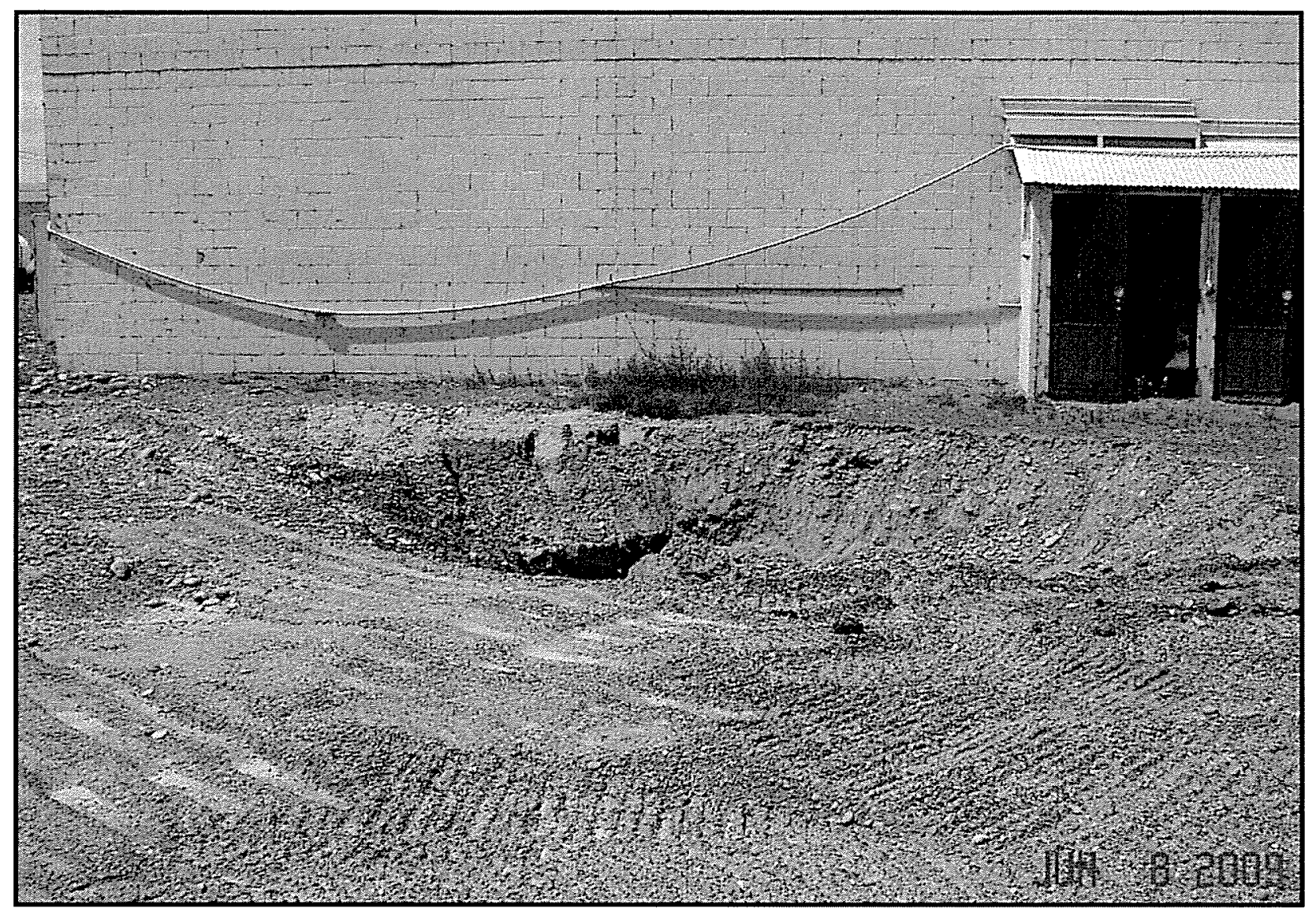

\subsection{6-NA SEWAGE LIFT STATION}

The 1706-NA Sewage Lift Station was used to pump water and sewage from the 1705-N Instrumentation and Electrical Facility. The lift station was a below-grade concrete structure consisting of two pumps with associated electrical conduit, junction box, and framework connected to a common 4-in. diameter galvanized steel piping located in a 6-ft diameter precast manhole with 6 -inch thick cylindrical walls. The lift station was approximately 15-ft deep with an 8 -in. thick concrete base. The 1706-NA Sewage Lift Station was used to collect sewer wastes for pumping to a discharge basin. It replaced an earlier septic tank and cesspool, which was located near the same location. The 1706-NA Lift Station was isolated in 2002, and it was demolished and excavated in 2009 (Figure 12).

Debris was disposed at ERDF and the excavation was backfilled with material from the $100-\mathrm{N}$ Borrow Pit. The associated cesspool, 100-N-22, was not removed and is to be remediated by FR. The excavation was backfilled with material from the 100-N Borrow Pit, and the site has been downposted and released. Final D4 documentation includes the GPERS and GPS surveys and sample data, all of which are included in the PDSR (WCH 2010b). 
Figure 12. 1706-NA Sewage Lift Station Excavation.

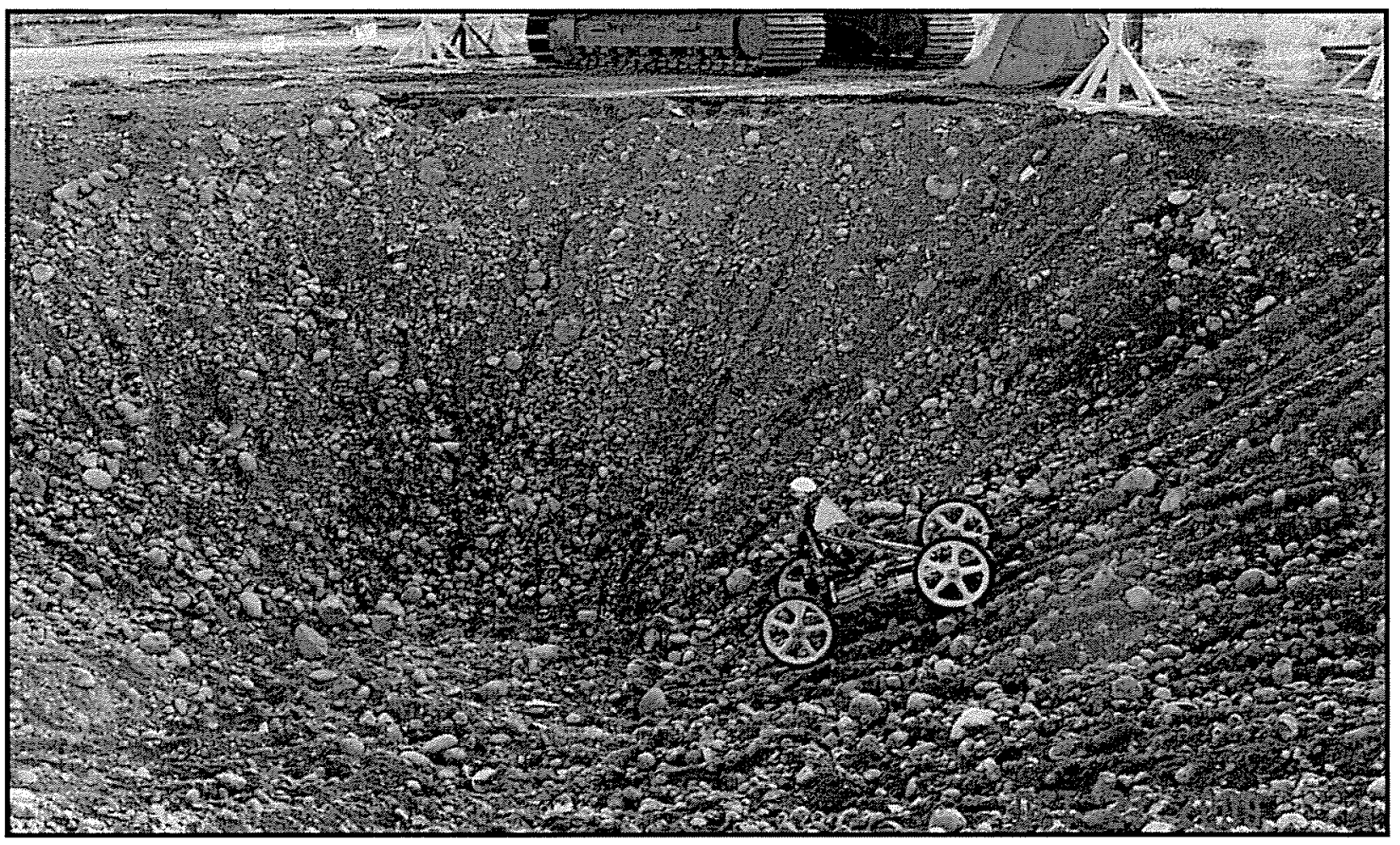

\section{$2.13 \quad 1904-D$ OUTFALL STRUCTURE}

The 1904-D Outfall Structure operated from 1944 to 1967 for discharge of reactor cooling water, and until 1975, for 100-D Area process sewer effluents. The site was located west of the 107-D Retention Basin. The site dimensions were $27 \mathrm{ft}$ by $14 \mathrm{ft}$ by $26 \mathrm{ft}$.

The 1904-D Outfall was a concrete feature that received reactor effluent water from the 107-D Retention Basin and discharged into the river (Figure 13). Effluent water exited the structure by two paths. Under normal operations, water discharged through two pipes that extended to the center of the river. The second exit path was via a flume/spillway that exited into the river. The outfall structure was partially demolished in 1998 and backfilled with clean soil.

A geophysical survey conducted in May 2004 identified anomalous subsurface features believed to be remains of the demolished concrete. From February to April 2009, the remnants of the 1904-D Outfall Structure were demolished and excavated for ERDF disposal. The southern edge of the 1904-D excavation was collocated with a section of concrete pipeline associated with the 100-D-31:7 waste subsite that currently is undergoing post-remediation close-out verification sampling and analysis (WCH 2009h). 
Figure 13. Demolition of the 1904-D Outfall Structure; Inset Shows Original Structure.

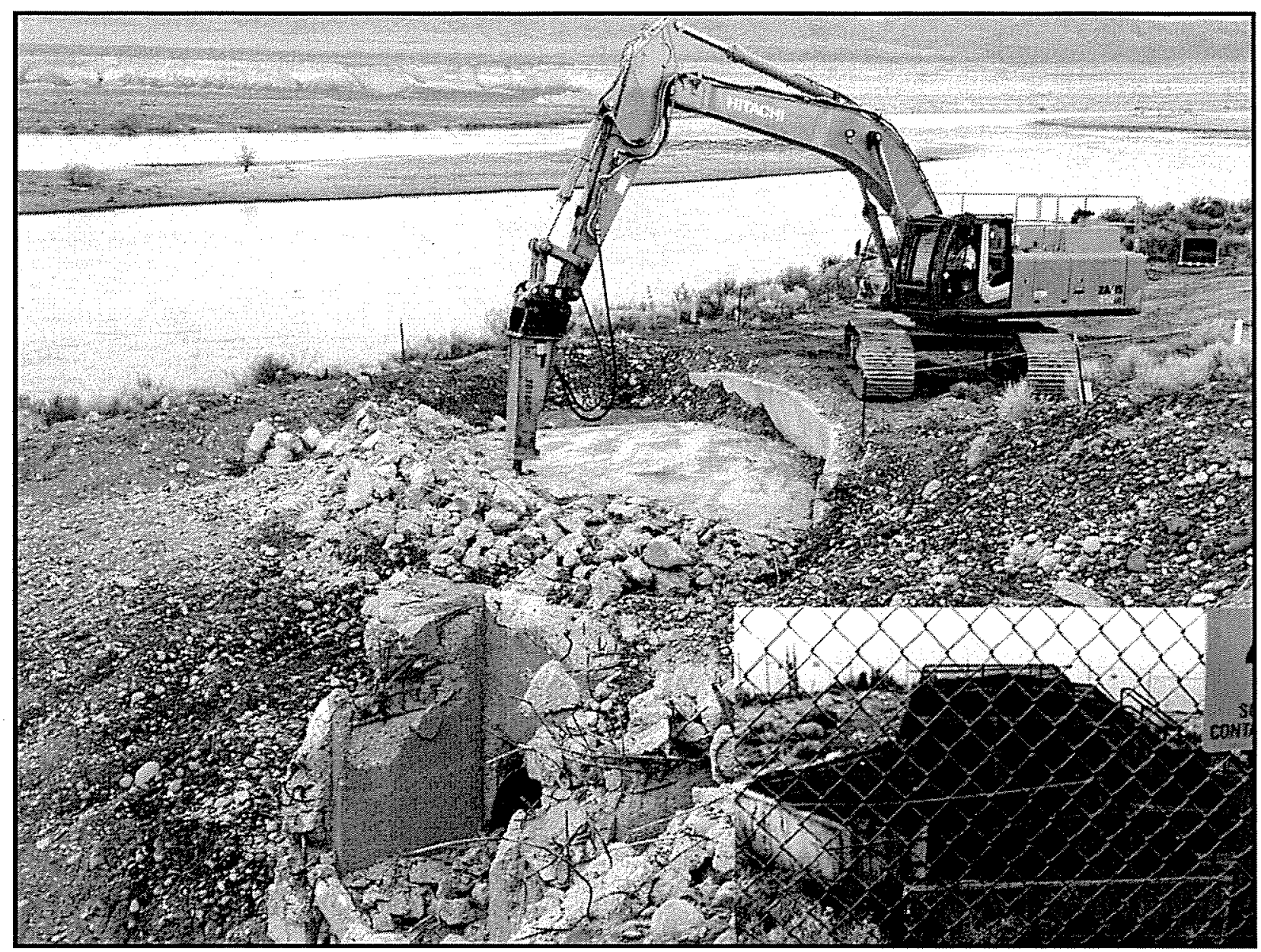

\subsection{MO-013 MOBILE OFFICE TRAILER}

MO-013, also known as $1158-\mathrm{N}$, was one of several mobile offices that were installed in the $100-N$ Area in the 1980s. It was a double-wide sheet metal and plywood trailer facility and contained ten offices (Figure 14). It was a 1977 Mico trailer, serial number 7219A-B, and was installed near the 1120-N Building between August 1985 and April 1986.

The 1158- $\mathrm{N}$ facility was used to provide office space for training personnel in the 100-N Area. Later, it also provided office space in support of the nearby Environmental Analytical Laboratory (EAL) facilities.

The MO-013 Mobile Office was demolished in late 2008. After demolition was completed the building debris was stockpiled, size-reduced, loaded out and disposed at ERDF in

February 2009. A minimal amount of soil was removed along with the building debris. The MO-013 site has been downposted and released. Final D4 documentation includes a predemolition GPS survey and sample data, which are included in the PDSR (WCH 2009f). 
Figure 14. Mobile Office Trailer MO-013 in 2005.

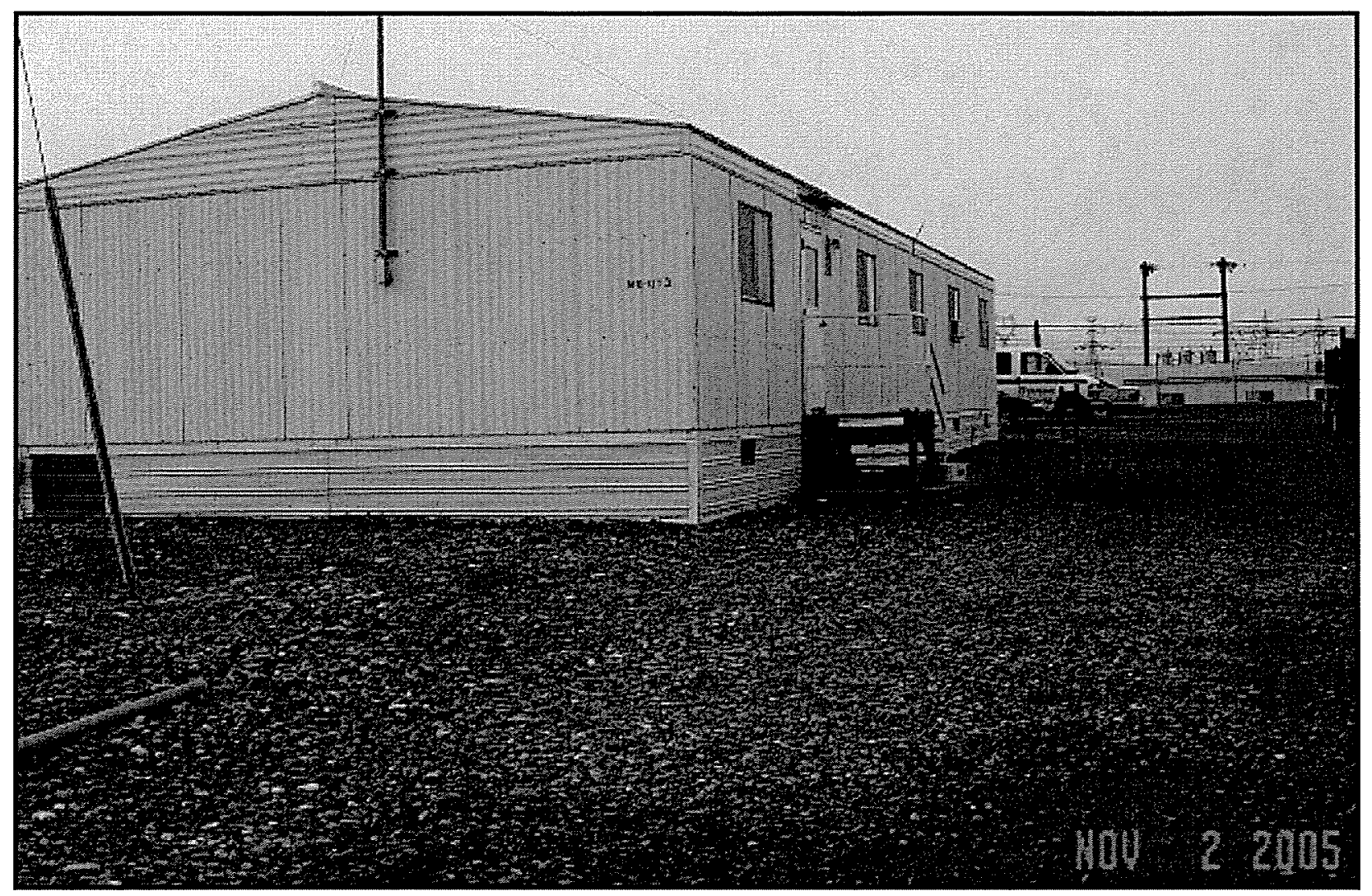

\subsection{MO-422 MOBILE OFFICE TRAILER}

The MO-422 Building (Figure 15) was a single-wide modular office trailer that measured $12 \mathrm{ft}$ by $32 \mathrm{ft}$. It was first located in the 200-W Area, and then was transported to a site northwest of the 105-DR Reactor Building where it served as the Field Support Trailer (BHI 1997b).

The MO-422 building was disconnected from utilities and relocated to the 100-K Area in 2007 (133075, HNF-EDC-08-36395). It was a "dry" trailer, with no water or sewer connections. At $100-\mathrm{K}, \mathrm{MO}-422$ facility was located southeast of the 183-KE Building, east of MO-442, and was used to support the WCH Rad-Con training program.

In 2008, the MO-422 trailer was relocated to $100-\mathrm{N}$ area. In 2009 it was towed intact to ERDF for disposal (WCH 2009g). 
Figure 15. MO-422 Before Disposal.

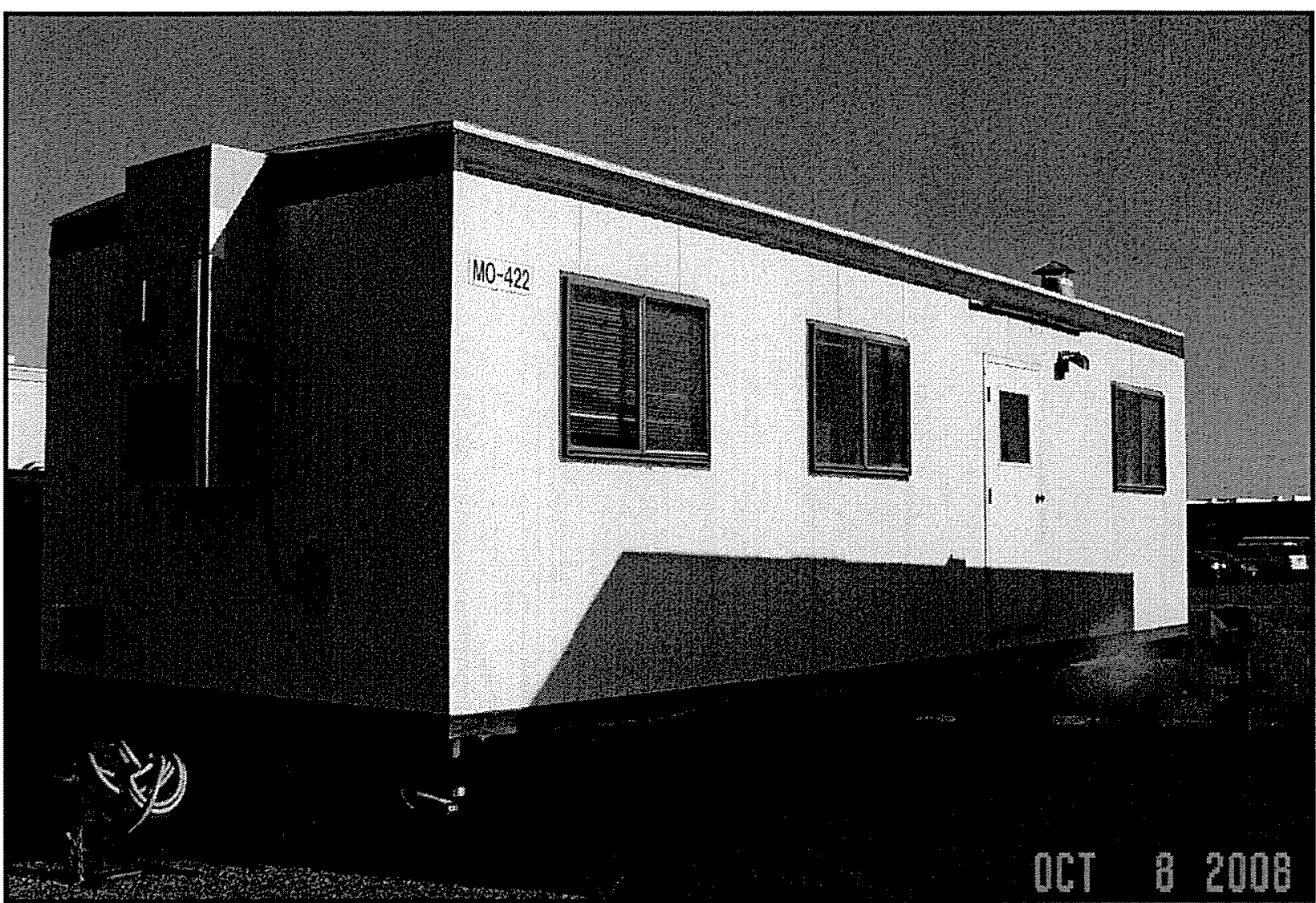

\subsection{MO-999 MOBILE OFFICE TRAILER}

The MO-999 building was a single-wide office trailer, manufactured in March 1991, and last located in the 100-N Area (Figure 16). It had previously been located in the 100-D Area, where it functioned as the supervisor's office during work for the 105-DR reactor ISS project. The MO-999 facility was relocated to the 100-N Area in 2003. At 100-N, MO-999 was located just south of the 151-N Switchyard, between MO-864 and MO-866. The MO-999 facility provided office space in the 100-N Area. One section of the facility was used as a count room and as a radiological control technician office ( $\mathrm{WCH} 2008 \mathrm{a})$.

The MO-999 trailer was towed intact to ERDF for disposal in 2009 (WCH 2009g). 
Figure 16. MO-999 Before Disposal (2006).

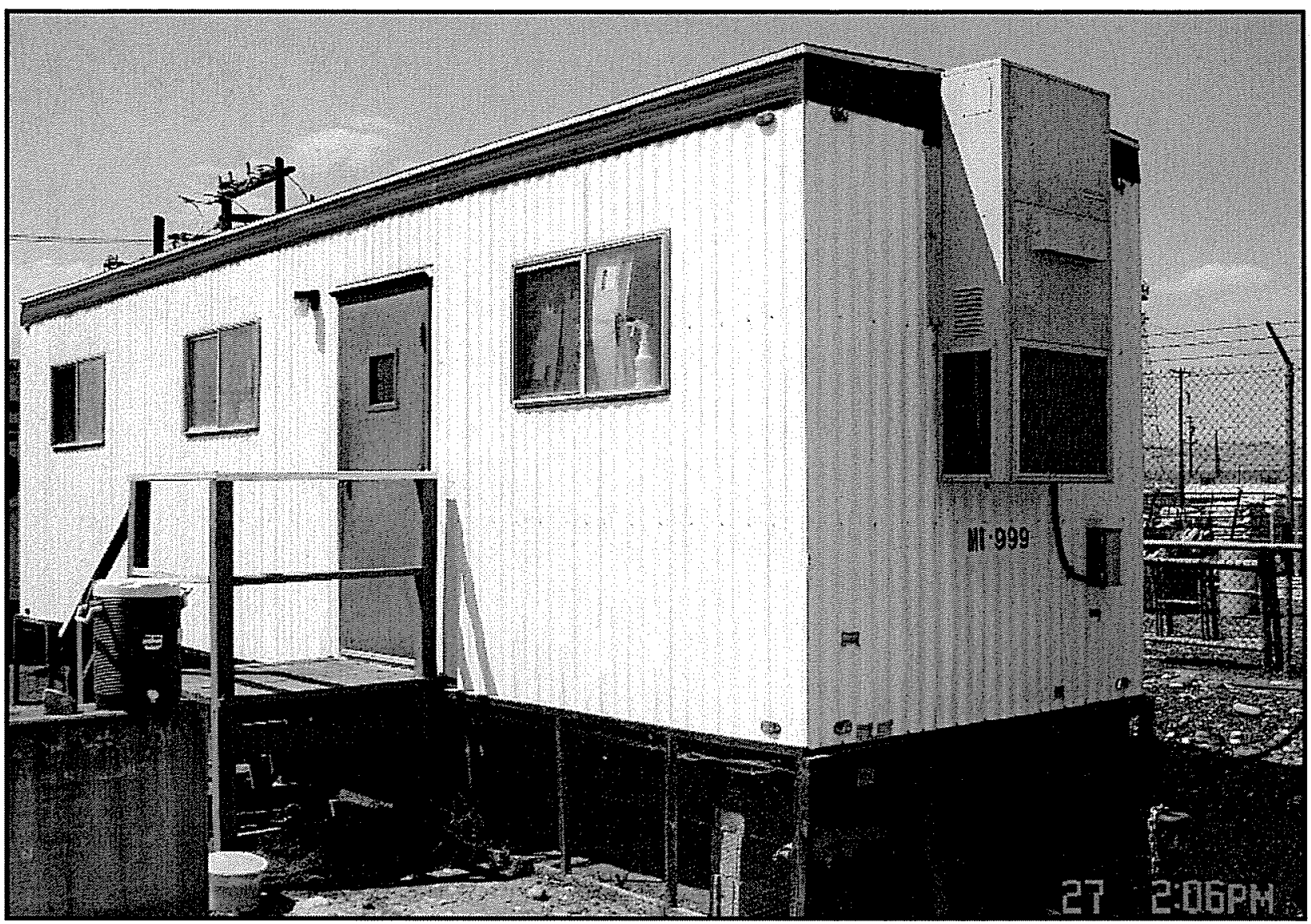

\subsection{PROJECT ACTIVITIES}

\subsection{ENGINEERING AND PERMITS}

The Removal Action Work Plan (RAWP) for 100-N Area Ancillary Facilities (DOE-RL 2006) was prepared to satisfy the requirements of the action memorandum (Ecology 1999), outlining how compliance with and enforcement of applicable regulations will be achieved for cleanup of 100 Area facilities. Additionally, the RAWP and the Environmental Control Plan for 100-N D4/ISS Activities (WCH 2006b) serve as the decommissioning plan and project management plan for the 100 Area project. The RAWP was prepared in accordance with Section 7.2.4 of the Hanford Federal Facility Agreement and Consent Order (Tri-Party Agreement) (Ecology et al. 1989) and was approved by the U.S. Department of Energy, Richland Operations Office and regulators. 
A plant forces work review was completed for the demolition of each building as indicated below:

- 11-N Change Room: Demolition of Six Ancillary Facilities at 100-N; 8850-006-04, Rev. 0, dated July 1, 2004

- 13-N Storage Building: Demolition of Remaining 100-N Excess Facilities; 18850-009-08, Rev 1, dated August 6, 2008

- 107-N Recirculation Facility: 107-N Demolition Project, 8850-011-04, Rev.1, dated August 3, 2004

- $108-\mathrm{N}$ Chemical Unloading Facility: Demolition of the $108 \mathrm{~N}$ Chemical Unloading/Storage Facility; 8850-004-06, Rev. 0, dated October 11, 2005

- 183-ND Resin Disposal Pit: Decontamination and Demolition of 163/183 Water Plant and 183N Pump Room; 8850-009-05, Rev. 0, dated March 21, 2005

- 183-F Clearwells: Characterization, Hazmat, Decommissioning \& Demolition of 183F; 8850-008-09, Rev. 0, dated March 6, 2009

- 1524-N Hazardous Waste Storage Pad and 1525-N Laydown Yard: Demolition of 1524-N and 1525-N; 8850-046-06, Rev. 0, dated July 3, 2006

- 1607-N1/1607 - no plant forces work review was found

- 1706-NA Sewage Lift Station: Demolition of 1705-NA and 1706-NA; 8850-016-06, Rev. 0, dated November 30, 2005

- 1904-D PFWR was not required for the WCH scope of work

- MO-013 Mobile Office Trailer: Demolition of Remaining Excess 100-N Facilities; 8850-009-08, Rev 1, dated August 6, 2008

- MO-422/MO-999 - no plant forces work review was found.

It was determined that the Davis-Bacon Act of 1931 prevailing wage rates for the work were not applicable for the buildings listed above, and the work was performed by plant forces.

An Initial Hazard Categorization (IHC) was performed on each building before demolition:

- 11-N, 13-N, 1524-N, and 1525-N are documented in IHC-2007-006 (WCH-2007)

- $107-\mathrm{N}$ is documented in $\mathrm{BHI}-01031$ (BHI 1997a) and $\mathrm{BHI}-01095$ (BHI 1998a)

- 183-ND and 108-N are documented in WCH-62 (WCH 2006a)

- $183-\mathrm{F}-\mathrm{IHC}$ is documented in IHC-2005-0008 (WCH 2005a).

- 188-D - An IHC was not required for the WCH scope of work 
- 1904-D - IHC is documented in BHI-01391 (BHI 2003)

- MO-013 is documented in $\mathrm{ICH}-2006-0036(\mathrm{WCH} 2008 \mathrm{~b})$

- MO-422- IHC not found

- MO-999, 1607-N1, 1607-N2, and 1706-NA are documented in IHC-2006-0036 (WCH 2008b)

Excavation work was undertaken after obtaining excavation work permits as follows:

- 11-N Change Room Concrete Pads: DAN-2945, DAN-2969, and DAN-2969-2

- 13-N Concrete Pad: DAN-2945, DAN-2969, and DAN-2969-2

- 107-N Recirculation Facility: DAN-3574, DAN-3319, and DAN 2550

- 108-N Chemical Unloading Facility, Transfer Pipes and Neutralization Pit: DAN-2881, DAN-2881-1, DAN-2881-2, and DAN-2881-3

- 183-ND - An excavation permit was not required for the WCH scope of work.

- 183-F - An excavation permit was not required for the WCH scope of work.

- 188-D - An excavation permit was not required for the WCH scope of work.

- The 1524-N Storage Pad: DAN-2945, DAN-2969, and DAN-2969-2

- The 1525-N Storage Area concrete pad: DAN-2945, DAN-2969, and DAN-2969-2

- 1607-N1: Sewage Tank: DAN-3651

- 1607-N2 Sewage Tank: DAN-3026-1

- 1706-NA Sewage Lift Station: DAN -2829-3

- 1904-D - An excavation permit was not required for the WCH scope of work.

- MO-013 Mobile Office Trailer: DAN-3508

- MO-422 - An excavation permit was not required for the WCH scope of work.

- MO-999 - An excavation permit was not required for the WCH scope of work.

\subsection{HAZARDOUS MATERIAL REMOVAL}

The scope of the demolition project included removing and properly disposing of hazardous materials (e.g., oils, grease, asbestos-containing material, mercury, lead, and polychlorinated biphenyls [PCBs]). All known hazardous materials were removed from inside and outside of the 
buildings prior to demolition. In most cases, some Class II non-friable asbestos-containing material (roofing material, floor tile, and vinyl sheeting) was left in place and removed during the demolition phase of the project. In these cases, all building demolition waste was treated as asbestos waste, and controls to minimize asbestos fiber release (fixatives, wet methods, and air monitoring) were used during demolition.

\subsection{UTILITY AND DRAIN ISOLATION}

All electrical, water, and telecommunications services were disconnected from the buildings prior to hazardous material removal operations. Floor drains were inspected for mercury and then sealed to provide isolation. Sanitary sewers to the building were disconnected during early deactivation activities and all drains were grouted.

\section{$3.4 \quad$ DEMOLITION OF STRUCTURES}

After the utilities were isolated, hazardous materials and equipment removal were performed, and the above-grade structures were ready for demolition. The building structures were demolished using excavator-mounted hydraulic shears, hydraulic hammers, and bucket-andthumb combination shovels. The foundations for these facilities were likewise removed. The debris was segregated for load-out and disposal. Standard ERDF roll-off containers with 6-mil liners were used to package and ship debris.

\subsection{SITE RESTORATION}

A list of conditions and postings for each building is listed below in Table 1.

Table 1. Site Conditions. (2 Pages)

\begin{tabular}{|c|l|l|}
\hline Building & \multicolumn{1}{|c|}{ Remaining Conditions } & \multicolumn{1}{|c|}{ Postings } \\
\hline $11-\mathrm{N}$ & $\begin{array}{l}\text { The building and concrete slab have been demolished } \\
\text { and disposed at ERDF. }\end{array}$ & Downposted and released \\
\hline $13-\mathrm{N}$ & $\begin{array}{l}\text { Above-ground structure and underlying concrete pad } \\
\text { demolished and disposed at ERDF. Site has been } \\
\text { backfilled. }\end{array}$ & Downposted and released \\
\hline $107-\mathrm{N}$ & East wall and basement foundation remain. & Posted as contamination area \\
\hline $108-\mathrm{N}$ & $\begin{array}{l}\text { All above-ground structures and concrete pads have been } \\
\text { demolished and disposed at ERDF. The underground } \\
\text { 120-N-5 Transfer Pipes and Neutralization Pit associated } \\
\text { with this site also have been removed. Site has been } \\
\text { backfilled. 108-N Acid Unloading Facility french drain is } \\
\text { listed in accepted WIDS associated with the 108-N } \\
\text { Chemical Unloading Facility. }\end{array}$ & Downposted and released \\
\hline $183-N D$ & $\begin{array}{l}\text { Above-ground debris and original fencing have been } \\
\text { removed and disposed at ERDF. Inlet piping remains. }\end{array}$ & Downposted and released. \\
\hline $183-\mathrm{F}$ & $\begin{array}{l}\text { Eastern clearwell structure is demolished to the concrete } \\
\text { floor. The western clearwell is intact and does not require } \\
\text { demolition/remediation. }\end{array}$ & Downposted and released. \\
\hline
\end{tabular}


Table 1. Site Conditions. (2 Pages)

\begin{tabular}{|c|l|l|}
\hline Building & \multicolumn{1}{|c|}{ Remaining Conditions } & \multicolumn{1}{|c|}{ Postings } \\
\hline $188-\mathrm{D}$ & $\begin{array}{l}\text { Demolition completed in 2009. Undergoing closeout } \\
\text { under the remaining sites verification package process. }\end{array}$ & None \\
\hline $1524-\mathrm{N}$ & $\begin{array}{l}\text { Aboveground structures and concrete pad have been } \\
\text { demolished and disposed at ERDF. Site has been } \\
\text { backfilled. }\end{array}$ & Downposted and released \\
\hline $1525-\mathrm{N}$ & Structure and slab removed, site backfilled. & Downposted and released \\
\hline $1607-\mathrm{N} 1$ & $\begin{array}{l}\text { The tank was demolished and excavated, and the } \\
\text { excavation backfilled. The cesspool remains. }\end{array}$ & Downposted and released \\
\hline $1607-\mathrm{N} 2$ & $\begin{array}{l}\text { The tank was demolished and excavated, and the } \\
\text { excavation backfilled. The 124-N-2 cesspool remains. }\end{array}$ & Downposted and released \\
\hline $1706-\mathrm{NA}$ & $\begin{array}{l}\text { The lift station was demolished and excavated, and the } \\
\text { excavation backfilled. The cesspool/septic tank remains }\end{array}$ & Downposted and released \\
\hline $1904-\mathrm{D}$ & $\begin{array}{l}\text { The above-ground structure was demolished. The } \\
\text { footings and below-ground structure remains. }\end{array}$ & Downposted and released. \\
\hline MO-013 & $\begin{array}{l}\text { Trailer has been demolished and disposed at ERDF. No } \\
\text { below-ground work was necessary. }\end{array}$ & Downposted and released \\
\hline MO-422 & $\begin{array}{l}\text { Trailer was towed intact to ERDF for disposal. No } \\
\text { underground work was necessary. }\end{array}$ & None \\
\hline MO-999 & $\begin{array}{l}\text { Trailer was towed intact to ERDF for disposal. No } \\
\text { underground work was necessary. }\end{array}$ & None \\
\hline $\begin{array}{l}\text { ERDF }=\text { Environmental Restoration Disposal Facility } \\
\text { WIDS }=\text { Waste Information Data System }\end{array}$ & \\
\hline
\end{tabular}

\subsection{COST AND COMPLETION}

Building completion costs and dates are tabulated below in Table 2.

Table 2. Cost and Completion Data. (2 Pages)

\begin{tabular}{|c|c|c|}
\hline Building & Total Cost (\$) & Completion Date \\
\hline 183-ND & 9,640 & June 30,2008 \\
\hline $13-N$ & 43,358 & July 31,2008 \\
\hline $108-N$ & 239,136 & December 17,2008 \\
\hline $1524-N$ & 101,620 & February 2,2009 \\
\hline $\mathrm{MO}-013$ & 29,551 & February 11, 2009 \\
\hline $11-\mathrm{N}$ & 21,810 & March 2, 2009 \\
\hline $13-N$ & 43,358 & March 2, 2009 \\
\hline $1525-\mathrm{N}$ & 26,872 & March 2, 2009 \\
\hline $\mathrm{MO}-422$ & * & May 5, 2009 \\
\hline $\mathrm{MO}-999$ & 4,318 & May 5, 2009 \\
\hline $183-\mathrm{F}$ & 159,520 & May 11, 2009 \\
\hline $1607-N 2$ & 5,898 & June 22,2009 \\
\hline $188-\mathrm{D}$ & 2,581 & June 30,2009 \\
\hline 1904-D & t & June 30,2009 \\
\hline $1607-\mathrm{N} 1$ & 16,116 & September 2, 2009 \\
\hline
\end{tabular}


Table 2. Cost and Completion Data. (2 Pages)

\begin{tabular}{|l|r|c|}
\hline Building & Total Cost (\$) & Completion Date \\
\hline $1706-\mathrm{NA}$ & 80,762 & November 3, 2009 \\
\hline $107-\mathrm{N}$ & $7,005,934$ & $\star$ \\
\hline
\end{tabular}

* Not Available

\subsection{RECYCLED MATERIAL AND WASTE DISPOSAL}

One of the objectives of the 100 Area demolition project was to support recycling and waste minimization. However, radiological contamination, primarily due to biological vectors (i.e., mud dauber wasps) is prevalent throughout the site. This prevented the salvage or offsite transfer of material and equipment from the buildings. Owing to the prevalent contamination, all of the building debris was shipped to ERDF for disposal.

\subsection{WASTE DISPOSAL}

Waste volume transferred to ERDF from the 100-N Building demolition project is listed in Table 3.

Table 3. 100-N Demolition Project Waste Transferred to ERDF. (2 Pages)

\begin{tabular}{|l|c|c|c|}
\hline Building & $\begin{array}{c}\text { Number of ERDF } \\
\text { Containers }\end{array}$ & Waste Volume $\left.\mathbf{( m}^{\mathbf{3}}\right)$ & Net Weight (tons) \\
\hline $\mathbf{1 1 - N}$ & 9 & 72 & 129 \\
\hline $\mathbf{1 3 - N}$ & 6 & 54 & 72 \\
\hline $\mathbf{1 0 7 - N}$ & 334 & 2,583 & 3695 \\
\hline $\mathbf{1 0 8 - N}$ & 123 & 1210 & 1976 \\
\hline $\mathbf{1 8 3 - N D}$ & 3 & 21 & 22 \\
\hline $\mathbf{1 8 3 - F}$ & 13 & 112 & 125 \\
\hline $\mathbf{1 8 8 - D}$ & $0^{\mathrm{a}}$ & 0 & 0 \\
\hline $\mathbf{1 5 2 4 - N}$ & 40 & 364 & 542 \\
\hline $\mathbf{1 5 2 5 - N}$ & 10 & 68 & 102 \\
\hline $\mathbf{1 6 0 7 - N 1}$ & 4 & 46 & 69 \\
\hline $\mathbf{1 6 0 7 - N 2}$ & 31 & 279 & 488 \\
\hline $\mathbf{1 7 0 6 - N A}$ & $0^{b}$ & 0 & 0 \\
\hline $1904-D$ & & & \\
\hline
\end{tabular}


Table 3. 100-N Demolition Project Waste Transferred to ERDF. (2 Pages)

\begin{tabular}{|l|c|c|c|}
\hline MO-013 & 14 & 84 & 40 \\
\hline MO-422 & 0 & NA & 2 \\
\hline MO-999 & 0 & NA & 2 \\
\hline
\end{tabular}

a No material "loaded-out." Ecology approved ash to be left in-place.

b No material "loaded-out." Completed by previous contractor.

\subsection{OCCUPATIONAL EXPOSURES}

\subsection{PERSONNEL INJURIES}

WCH personnel worked a total of approximately 137,930 hours (manual and non-manual, not including subcontractors) from December 1, 2008 to December 31, 2009 on the 100 Area D4/ISS project. There were 10 Occupational Safety and Health Administration (OSHA) Recordable Injuries ( 8 were Recordable Only; 2 were DART [i.e., Lost Time cases]). There were also 27 First Aid cases during this time period associated with the 100 Area D4/ISS Project.

\subsection{PERSONNEL RADIOLOGICAL EXPOSURES}

No clothing contamination and no skin contamination incidents occurred during demolition of the 100 Area buildings discussed in this report. Workers received 7,350.2 person-mrem of radiological exposure from December 2008 to December 2009 during their support of D4 activities associated with the buildings discussed in this report. All boundary air sample results were below procedural action levels for the duration of the work performed.

\subsection{LESSONS LEARNED}

\subsection{CONTROLLING EMPLOYEE ACCESS IN WORK ZONES}

In an effort to minimize employee injuries, $\mathrm{WCH}$ continued to implement a procedure requiring a temporary fence around demolition areas. This helped to control employee access in and around work zones. It is also effective in establishing the minimum distance people can be from demolition. The superintendent and the field safety representative control the areas and limit access inside the fence lines. This reduces the risk of injury in and around the work zone. 


\subsection{REFERENCES}

BHI, 1994, 100N 100-F Reactor Site Technical Baseline Report Including Operable Units 100-FR-1 and 100-FR-2, BHI-00031, Rev. 0, Bechtel Hanford, Inc., Richland, Washington.

$\mathrm{BHI}, 1995,100 \mathrm{~N}$ Facility Endpoint Criteria and Turnover, 13N Pipefitters Storage Building, CNN 521130, Bechtel Hanford, Inc., Richland, Washington.

BHI, 1997a, Preliminary Hazard Classification for Building 107-N, BHI-01031, Rev. 1, Bechtel Hanford, Inc., Richland, Washington.

BHI, 1997b, Scope of Work for Insecticide and Rodenticide Application for Bechtel Hanford, Inc., 000X-SW-G0079, Bechtel Hanford, Inc., Richland, Washington.

$\mathrm{BHI}, 1998 \mathrm{a}$, Final Hazard Classification and Auditable Safety Analysis for Building 107-N, BHI-01095, Rev. 2, Bechtel Hanford, Inc., Richland, Washington.

BHI, 1998b, Waste Site Reclassification Form, Remaining Sites Verification Package for 126-D1, 184-D Powerhouse Ash Pit, WSRF 98-06, Bechtel Hanford, Inc., Richland, Washington.

$\mathrm{BHI}, 2003$, Preliminary Hazard Classification for the Remediation of the 100-D/DR Area Remaining Sites, BHI-01391, Rev. 2, Bechtel Hanford, Inc., Richland, Washington.

BHI, 2004, Facility Inspection Summaries for the 11-N and 13-N Facilities, CNN 113664 to R. G. Egge from D. Jacques, Bechtel Hanford, Inc., Richland, Washington.

Davis-Bacon Act of 1931, 40 U.S.C. 276a, et seq.

DOE/RL, 2004, Waste Characterization Sampling and Analysis Plan for the 107-N Basin Recirculation/Cooling Facility, 1310-N Pump House and Liquid Storage Tank, and 1314 Liquid Waste Loadout Complex, DOE/RL-2004-15, U.S. Department of Energy, Richland Operations Office, Richland, Washington.

DOE-RL, 2006, Removal Action Work Plan for 100-N Area Ancillary Facilities, DOE/RL-2002-70, Rev. 2, U.S. Department of Energy, Richland Operations Office, Richland, Washington.

Ecology, EPA, and DOE, 1989, Hanford Federal Facility Agreement and Consent Order, Washington State Department of Ecology, U.S. Environmental Protection Agency, and U.S. Department of Energy, Olympia, Washington.

Ecology, 1999, "Action Memorandum for the 100-N Area Ancillary Facilities," LTR 064829 from M. A. Wilson to L. Piper, U.S. Department of Energy, Richland Operations Office, Washington State Department of Ecology, Richland, Washington, January 6.

WCH, 2005a, Initial Hazard Categorization - 100F Remaining Sites Material at Risk Calculation has been Revised to Incorporate Results of Recent Characterization Sampling, IHC2005-0008, Washington Closure Hanford, Richland, Washington. 
$\mathrm{WCH}, 2005 \mathrm{~b}$, "Post-Demolition Summary Report for the 108-N Chemical Unloading Facility and the 120-N-5 Transfer Line Trench and Neutralization Pit," CNN 143099 to M. E. Allen from M. T. Stankovich, Washington Closure Hanford, Richland, Washington, February 4.

WCH, 2006a, Initial Hazard Categorization for the 100-N Ancillary Facilities, WCH-62, Rev. 0, Washington Closure Hanford, Richland, Washington.

WCH, 2006b, Waste Site Reclassification Form, Remaining Sites Verification Package for 126-F-2, 183-F Clearwells, WSRF 2006-017, Washington Closure Hanford, Richland, Washington.

WCH, 2007, Initial Hazard Categorization - D4 of 11-N, 13-N, 124-N, and 1525-N Concrete Pads and Laydown Area, IHC-2007-0006, Rev. 1, Washington Closure Hanford, Richland, Washington.

WCH, 2008a, "Historical Site Assessment for MO-544, MO-545, MO-806, MO-807, MO-808, MO-809, MO-864, MO-865, MO-866, MO-868, MO-999, HO-64-5865, HO-64-5924, HO64-6378, HO-64-6385, HO-64-15042, HO-64-18586, Connex 238876, and Connex 251205," CNN 136492 to J. M. Carranco from M. T. Stankovich, Washington Closure Hanford, Richland, Washington, October 9.

WCH, 2008b, Initial Hazard Categorization, Deactivation, Decontamination, Decommissioning, and Demolition (D4) of Miscellaneous Buildings and Ancillary Structures in 100-N Area

(See Table 1), Including Loading, IHC-2006-0036, Rev. 2, Washington Closure Hanford, Richland, Washington.

WCH, 2009a, Identification and Protection of a Bat Colony in the 183-F Clearwell: Mitigation of Bat Habitat on the Hanford Site, WCH-312, Rev. 0, Washington Closure Hanford, Richland, Washington.

WCH, 2009b, "Post-Demolition Summary Report for the 11-N Concrete Pad, 13-N Concrete Pad, 1524-N Hazardous Waste Pad and 1525-N Laydown Storage Area," CNN 143639 to M. E. Allen from M. T. Stankovich, Washington Closure Hanford, Richland, Washington, March 10.

WCH, 2009c, "Post-Demolition Summary Report for the 100-N Sanitary Sewer System No. 1 Tank (1607-N1, 124-N-1)," CNN 146959 to M. E. Allen from M. T. Stankovich, Washington Closure Hanford, Richland, Washington, September 21.

WCH, 2009d, "Post-Demolition Summary Report for the 100-N Sanitary Sewer System No. 2 Tank (1607-N2, 124-N-2)," CNN 145646 to M. E. Allen from M. T. Stankovich, Washington Closure Hanford, Richland, Washington, July 14.

WCH, 2009e, "Post-Demolition Summary Report for the 183-ND Resin Disposal Pit," CNN 143638 to M. E. Allen from M. T. Stankovich, Washington Closure Hanford, Richland, Washington, February 23.

WCH, 2009f, "Post-Demolition Summary Report for the MO-013 Mobile Office Trailer," CNN 143637 to M. E. Allen from M. T. Stankovich, Washington Closure Hanford, Richland, Washington, March 11. 
WCH, 2009g, "Post-Demolition Summary Report for the MO-422, MO-544, MO-864, MO-999

Mobile Offices and HO-64-3549, HO-64-5924, HO-64-5863, HO-64-6064, HO-64-6378,

HO-64-18586 Trailers," CNN 145557 to M. E. Allen from M. T. Stankovich, Washington

Closure Hanford, Richland, Washington, July 7.

WCH, 2009h, Work Instruction for Verification Sampling of 116-D-5, 1904-D Outfall Structure, 0100D-WI-G0059, Washington Closure Hanford, Richland, Washington.

WCH, 2010a, "Post-Demolition Summary Report for the 188-D Ash Disposal Basin,"

CNN 149385 to M. E. Allen from K. G. Finucane, Washington Closure Hanford, Richland, Washington, March 9.

WCH, 2010b, "Post-Demolition Summary Report for the 1706-NA Sewage Lift Station," CNN 149292 to M. E. Allen from K. G. Finucane, Washington Closure Hanford, Richland, Washington, February 18.

WCH, 2010c, RCC Stewardship Information System Facility Summary Report, 183-ND, Resin Disposal Pit, Washington Closure Hanford, Richland, Washington. 


\section{DISTRIBUTION}

U.S. Department of Energy

Richland Operations Office

R. L. Guercia S5-06

Washington Closure Hanford

M. E. Allen $\quad \times 5-50$

D. E. Reese $\quad$ X5-50

D. J. McBride L7-11

C. S. Cearlock H4-22

T. R. Edmundson H4-21

M. D. Flannery X5-50

K. J. Koegler L7-11

J. A. Lerch H4-22

M. L. Proctor H4-22

B. D. Smith L7-11

J.P. Harrie X5-50

Document Control H4-11

DOE-RL Public Reading Room H2-53

Hanford Technical Library $\quad$ P8-55 